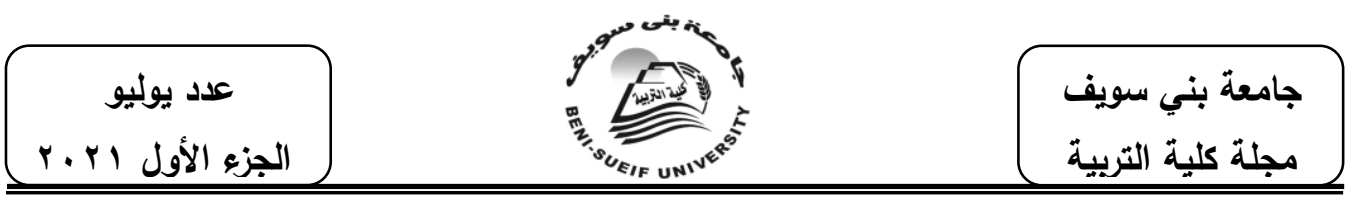

فاعلية خلية التعلم في تتمية مهارات القراعة المكثفة ومهارات التفاوض لاى طلاب المرحلة الثانوية

\title{
د/ عبيز أحمد علي
}

أستاذ المناهج وطرق تدريس اللغة العربية المساعد اهدي

كلية التربية- جامعة بني سويف

مستخلص

هدف البحث الحالي إلي التحقق من فاعلية خلية التعلم في تتمية مهارات القراءة المكثقة ومهارات التفاوض لدى طلاب المرحلة الثانوية،وتصميم قائمة لمهارات القراءة المكثقة المناسبة لطلاب الصف الأول الثانوي، وتصميم قائمة مهارات التفاوض المناسبة لطلاب الصف الأول الثانوي. وتكونت عينة البحث من(1/) من طلاب الصف الأول الثانوي ، وقامت الباحثة بتصميم عدة أدوات بغرض جمع البيانات هي: (إعداد قائمة بمستويات القراءة المكثفة لطلاب

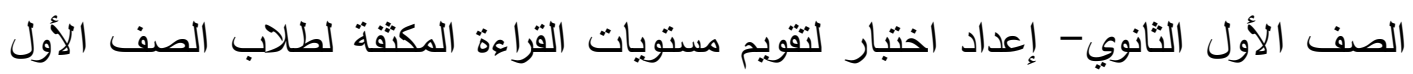
الثانوي - استنيان التفاوض وبرنامج تعليمي قائم على خلية التطلم ، وانتهى البحث إلى النتائج التالية :

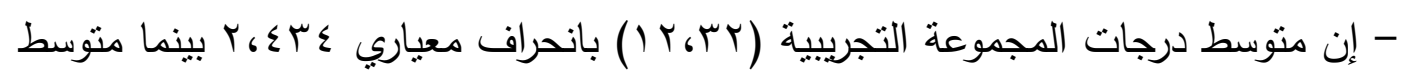

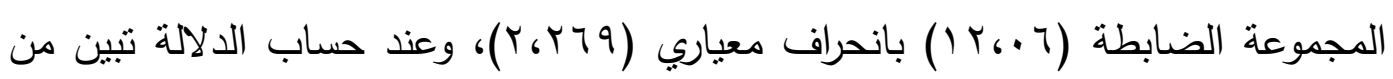

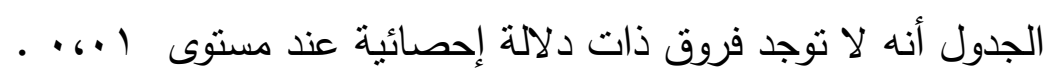

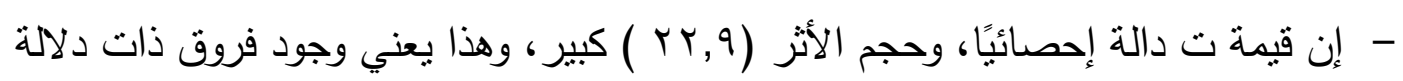
إحصائية بين متوسطي درجات الطلاب المجموعة التجريبية في مجمل الأداء الكلي لمهارات القراءة المكثفة (الفهم المباشر -الفهم الاستتتاجى-الفهم الناقد- الفهم التذوقي - الفهم الابتكارى) لصالح طلاب المجموعة التجريبية، وذلك في التطبيق البعدي للاختبار .

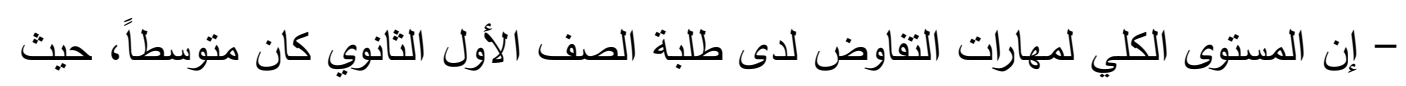

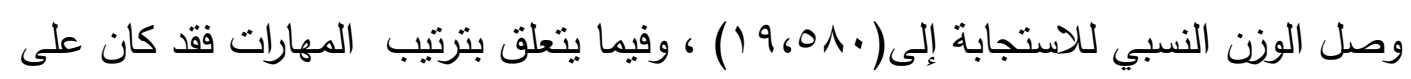

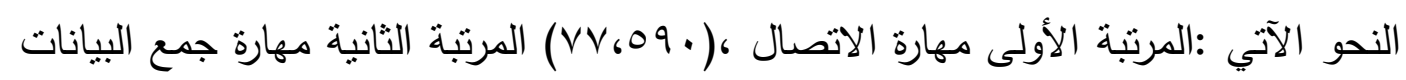

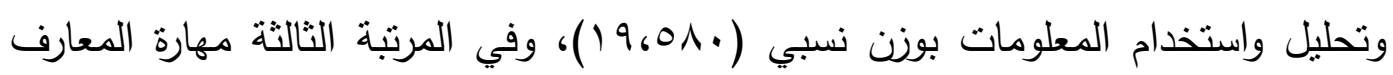




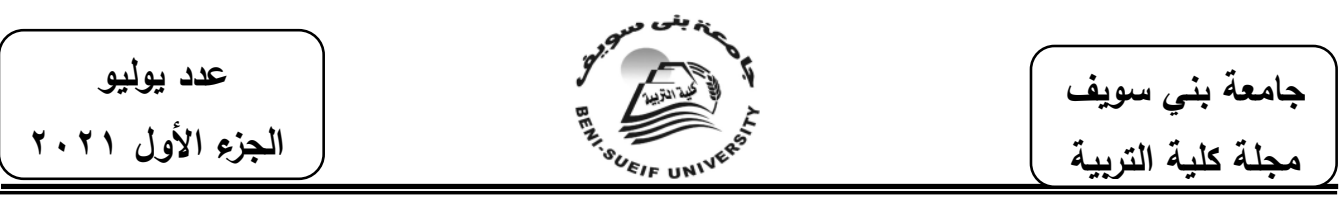

المتعددة ذات الصلة بالتفاوض بوزن نسبي( . 09،0) وفي المرتبة الرابعة مهارة اتخاذ القرار التفاوضي بوزن نسبي(•^^،^^) وفي المرتبة الخامسة مهارة الاستماع بوزن نسبي $\cdot\left(V r_{6} \varepsilon V \cdot\right)$

الكلمات المفتاحية :

خلية التعلم.

مهارات القراءة المكثفة.

مهارات التفاوض. 


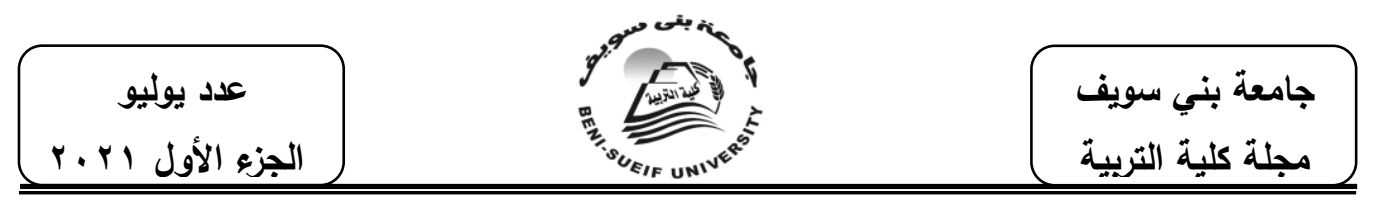

The learning strategy cells in developing the intensive reading skills and negotiation skills of high school students

\section{Abstract}

The purpose of the current researcher is to verify the effectiveness of the learning cell in developing the intensive reading skills and negotiation skills of high school students, Study tools were formed: designing a list of intensive reading skills suitable for first-grade secondary students, and designing a list of appropriate negotiation skills for first-grade secondary students. The study eye consisted of (68) students of the first grade of secondary school, and the researcher designed several tools for the purpose of collecting data, namely: (Preparing a list of intensive reading levels for first-grade secondary students - preparing a test to assess the levels of intensive reading for first-grade secondary students - a negotiation questionnaire and an educational program) Based on the use of the learning cell, and the study ended with the following results.

-The average of the experimental group scores is $(12,32)$ with a standard deviation of 2,434 , while the average of the control group $(12,06)$ (with a standard deviation $(2,269)$, and when calculating the significance, it was found from the table that there are no statistically significant differences at the 0 level, 01

-That the value is statistically declining, and the size of the effect 9,22 is large, and this means that there are statistically significant differences between the mean scores of the experimental group students in the overall performance of the intensive reading skills (direct comprehension- deductive understanding-critical understanding-taste understanding-creative understanding)in favor of Experimental group students, in the post-test application

-That the total level of negotiation skills of first-grade secondary students was average, as the relative weight of the response reached $(19,580)$, and with regard to the order of skills, it was as follows: First-class communication skill, $(77,590)$, second-place plural skill Data, analysis and use of information with relative weight $(19,580)$, and in the third place the skill of multiple knowledge related to negotiation with relative weight $(59,50)$, and in the fourth place the skill of negotiating decision-making with relative weight $(89,480)$ and in the fifth place is the skill of listening with relative weight $(\mathbf{7 3 , 4 7 0})$

Key words:Learning Cell-Intensive Reading Skills-and Negotiation Skills 


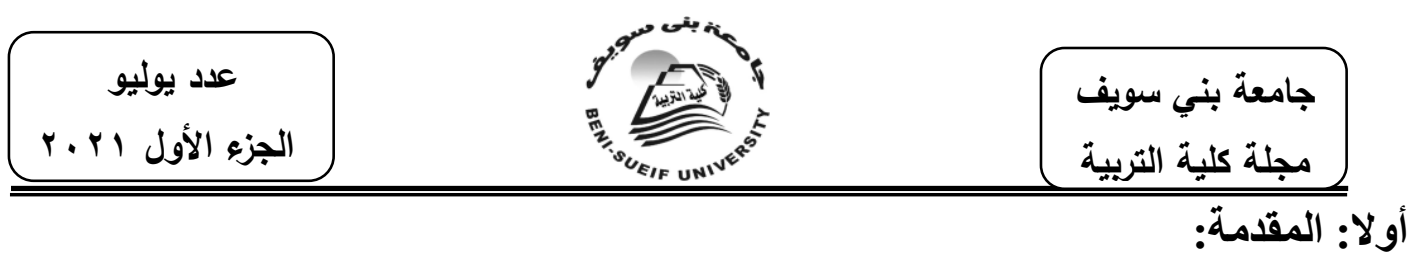

تعد اللغة من أهم الظواهر الاجتماعية التي أنتجها العقل البشرى خلال مراحل تطورهاءوترتبط ارتباطا عضويا بجميع المعارف الإنسانية، وارتباطها بمعارف الإنسان يؤكد الهي دورها فى تحقيق منزلته ومكانته العليا بين الكائنات الأخرى، وذلك لتميز الإنسان بها دون سائر المخلوقات،حيث فضله الله سبحانه وتعالى على سائر مخلوقاته بامتلاكه للغة ومعجزة الإدراك المعرفي التي تمكن الإنسان من تحويل التفكير إلى لغة، واللغة إلى تفكير؛ مما يتيح

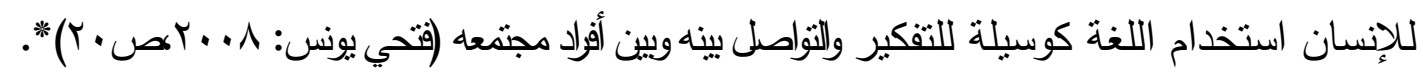
وأما كون اللغة وسيلة للتفكير الإنساني فإنما يظهر من العلاقة الوثنقة بين اللغة والتقكير ؛

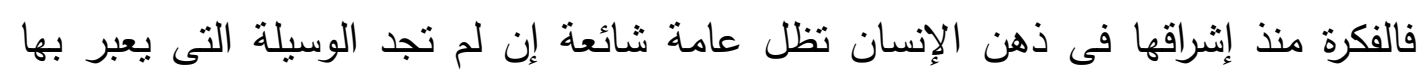

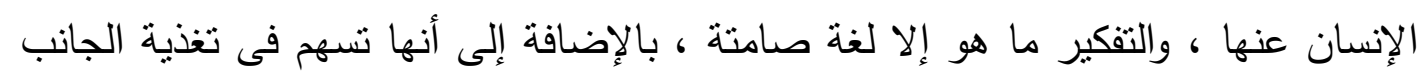
العاطفي للإنسان عن طريق التذوق الجمالي لروائع الثعر والأدب،كما ترتقي بالجانب الخلقي

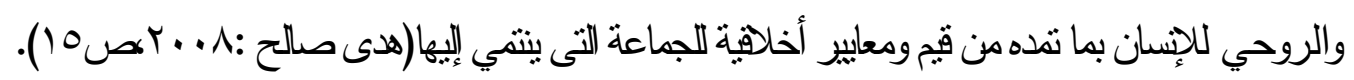

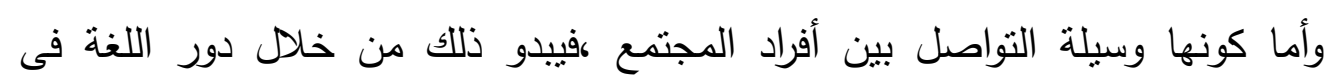
تحقيق التفاهم بين أعضاء الجماعة الإنسانية ،فالمجتمع فى كل شأن من شئونه ؛ سواء منها ما يتصل بقضاء حاجاته الأولية أو ما يتصل بتتظيم نواحي أنشطته المختلفة لا يستغنى عن التهن

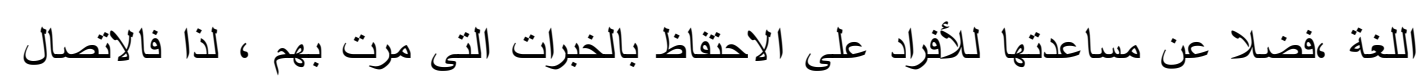
كوظيفة من وظائف اللغة لا يقتصر الأمر فيه على أفراد المجتم في عصر واحد بل أنه بمنذ إلى الى فئل

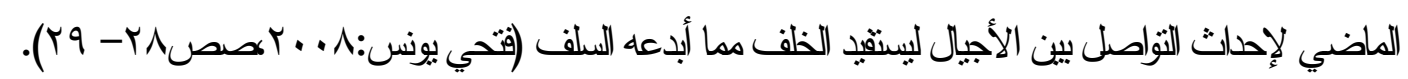
ومما سبق تتجلى أهمية اللغة لكل من الفرد والمجنمع ،حيث إنها تمثل للفرد أداته للتعبير

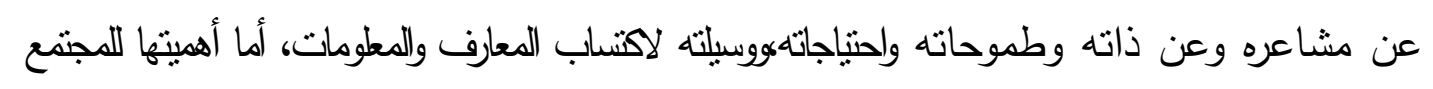

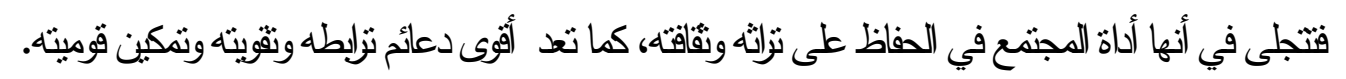
ولهذه الأهمية للقراءة فقد احتلت القراءة حظا ونصيبا وافراً من وقت تدريس اللغة العربية في المرحلة الثانوية، لأنها تساعد الطلاب على اكتساب المعارف، ونثير لليهم الرغبة في الكثابة

* تم التوثيق بذكر الاسم الأول والأخير للمؤلف 
الموحية، حيث تزداد معرفة الطلاب بالكلمات والجمل والعبارات المستخدمة في الكلام والكتابة، كما أنها تساعدهم في تكوين إحساسهم اللغوي، وتذوقهم لمعاني الجمال فيما

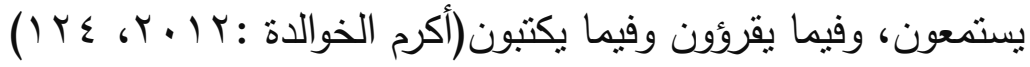
ثانيا: الإطار النظري : ويتتاول القراءة المكثفة ومهاراتها، وتصنيفاتها. التفاوض، مفهومه ومهاراته وشروطه، ثم يتتاول خلية التعلم مفهومها وخطوات إستراتيجياتها

\section{1- القراعة المكثقة وميهاراتها:}

شهد الأدب التربوي في ميدان تعليم القراءة وانتقال أثز ذللك في التعامل بوعي مع عناصر النص المقروء بحوثا عديدة أكدت العلاقة بين التقدّم في القراءة، وانعكاس ذلك على ألى فنون اللغة ومهاراتها الأخرى، وقد وصفت في كثير من البحوث بأنها علاقة تكاملية، تفاعلية، فالاستيعاب الجيد يزيد من ثقة القارئ بنفسه، ويقوي مفرداته، ويوسع دائرة معارفه، ويتيح لله تعرف طريقة بناء النص، و الأنماط المستخدمة فيه. كما يزوده بمقدار وافر من المعلومات

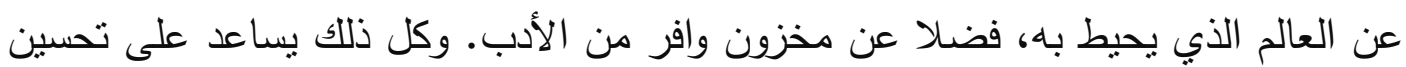
كتابته، وقدرته على التحدث والاستماع ولا شك أن هذا التصوّر ترجمة لمبادئ النظرية الكلية التي ترى أن الإنسان يكتسب اللغة في إطار كلي، وفي سياقات اجتماعية توفر لله مزيدا من

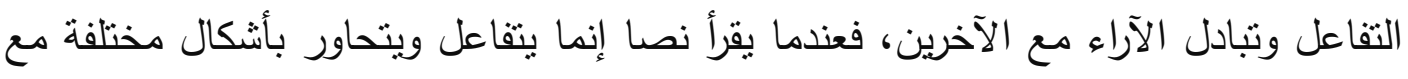
كاتبه، ومع ما يتتاول من أفكار وآراء ومقترحات، وعندما يكتب لجمهور معين يمارس أنثالا من التساؤلات والحوارات المسموعة وغير المسموعة مع القارئ أو جمهور القرّاء المستهدفين بالكتابة، ويتبادل معهم الآراء والتصورات حول ما سيكتب، وبستمر في ذلك منذ لحظة

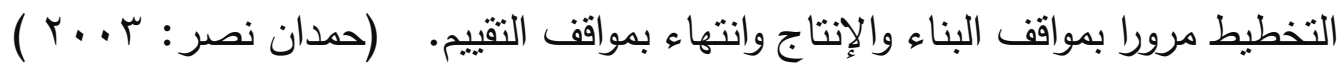

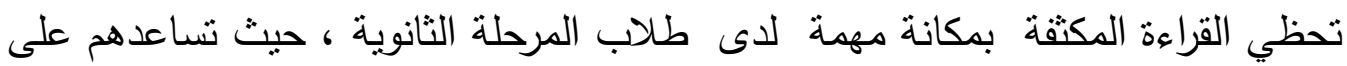
فهم ما يقرؤون من نصوص فهما كليا عاما ، وجزئيا تفصيليا، وتساعدهم كذلك على إدراك النصوص ، ومعرفة جوانبها ومكوناتها وأساليب نتظيمها والوقوف علي أهم تفاصيلها ، ونقدها (حسن شحاته، 7 (. Y، • (1)). والقراءة المكثفة هي ذلك النموذج من القراءة التي تجري داخل الفصل بهدف تتمية مهارات القراءة عند الطلاب، وزيادة رصيدهم اللغوي، ويتم اختيار 


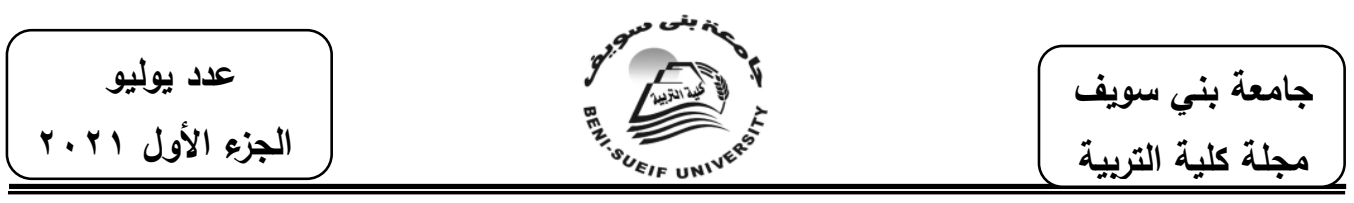

نصوص على مستوى من الصعوبة يتم تدريب الطلاب من خلالها على اكتساب مهارات

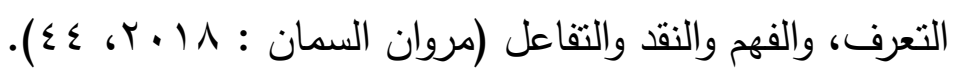

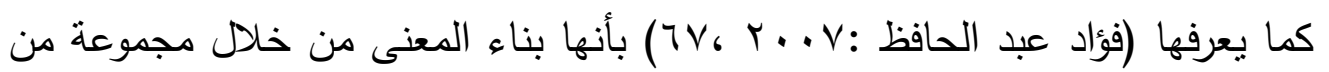
العمليات المعقدة والمتفاعلة والقائمة على توظيف خبرات القارئ السابقة، ومهاراته في التفكير الناقد، وعمل الاستتناجات، ويضيف هذا التعريف بعض مهارات القارئ فى الوصول إلى معنى المقروء متمثنلا فى قدرته على توظيف الخبرة السابقة ومهارات التفكير الناقد فى لـ فه استخلاص المعنى من النص المقروء. وتعرفها (Snow:2012) بأنها عملية استخلاص وبناء المعنى من خلال التفاعل مع

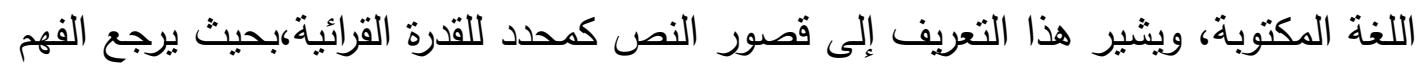
فى القراءة للتفاعل بين القارئ والنص والسياق الذي تتم فيه عملية القراءة . ويعرف (Duke \& Pearson: 2015) بأنها عملية استخلاص المعنى من المقروء حيث يتعرف القارئ على الكلمات ويربط بين الرمز ومعناه، ويعالج الجمل والعبارات بطلاقة كافية لاستخلاص المعنى،بحيث يحصل القارئ على المعنى الذي أراده الكاتب دون مواجهة الكاتب وجها لوجهة اعتمادا على استتطاق النص واشتقاق المعنى منه باستتاد القارئ إلى لى لهئ خبرته السابقة ودمج هذه الخبرة مع ما حصله من معنى من النص المقروء ومراقبة القارئ

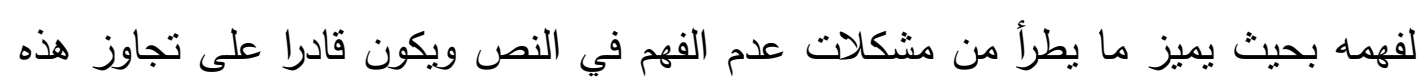

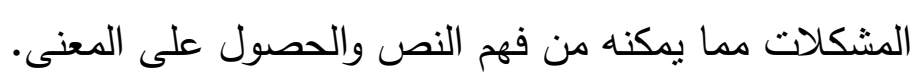

\section{- - تصنيف مهارات القراءة المكثفة}

لقد تعدد تصنيف مهارات القراءة المكثفة بتعدد الباحثين ،وذللك لما يوليه البحث في مجال القراءة المكثفة و لكي يستطيع القارئ الحصول على المعنى من المقروء لا بد من ثتوافر لديه مجموعة من المهارات التى تعينه على التمكن من استخلاص المعنى من النص القرائى ،ويقصد بمهارات القدرة القرائية تلك المهارات التي تساعد القارئ أن يفهمهويستعمل المادة

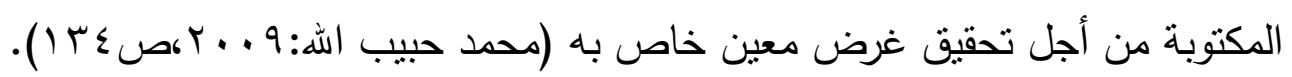




\section{عدد يوليو

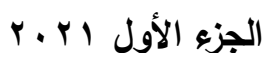

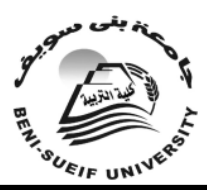

جامعة بني سويف

مجلة كلية التربية

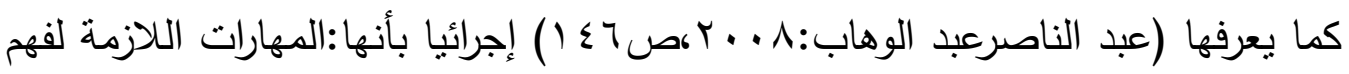
النص المقروءوالتي تعبر عن مدى قدرة القارئ على استيعاب النص والتفاعل معه ،كما

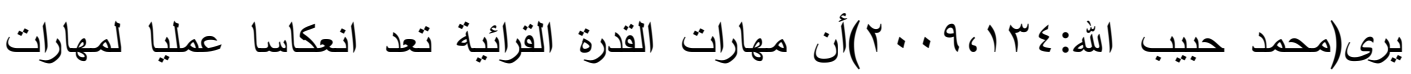
التفكير ،لما للعلاقة الوثيقة بين القدرة القرائية والقراءة والتقكير،حيث تتكامل مهارات القدرة القرائية،وتتتوع وقد تتداخل فيما بينها ،وربما تسلم إحداها إلى الأخرى،إلا أنها ليست منفصلة عن بعضها البعض بحال من الأحوال،فهي كل مترابط يؤدى فيه السابق إلى اللاحق.

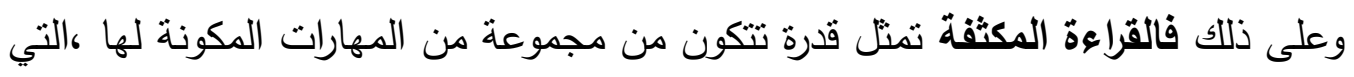
تتكامل فيما بينها ، والتي يصعب قياسها جميعا ،أو تقويم امتلاك الطلاب لكل مهاراتها

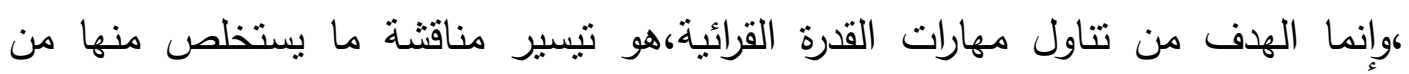
مستويات ومهارات يسهل تصنيفها طبقا لما سيتم تحديده من مستوياتهويرى(فتحي

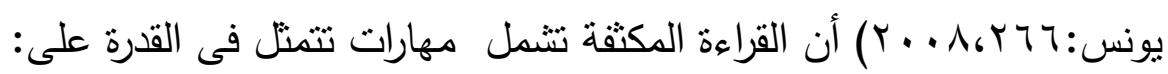
1- (إعطاء الرمز معناه.

r- فهم الوحدات الأكبر ،كالعبارة والجملة والفقرة والقطعة كلها. r- القراءة في وحدات فكرية. ع - فهم الكلمات من السياق،واختيار المعنى الملائم له. 0- تحصيل معاني الكلمة. 1- اختيار الأفكار الرئيسة وفهمها. V - فهم التنظيم الذي اتبعه الكاتب.

$$
\text { 9- } 1 \text { - الاستتناج. }
$$

• 1 - تقويم المقروء، ومعرفة الأساليب الأدبية ، والنغمة السائدة، وحالة الكاتب وغرضه.

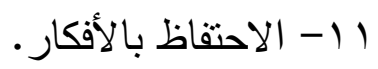
r ا - تطبيق الأفكار وتفسيرها في ضواء لاهواء الخبرة السابقة. 


\section{عدد يوليو

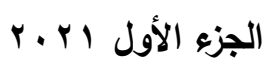

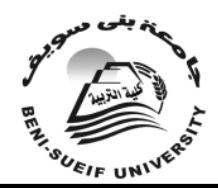

جامعة بني سويف مجلة كلية التربية

ومن خلال استعراض القوائم السابقة يبدو لنا أن بينها كثيرا من نقاط الالتقاء قد تصل لحد التطابق والتشابه،ولا ضير فى ذلك فهي متداخلة منتابكة ومتكاملة فيما بينها،حيث يرجع هذا

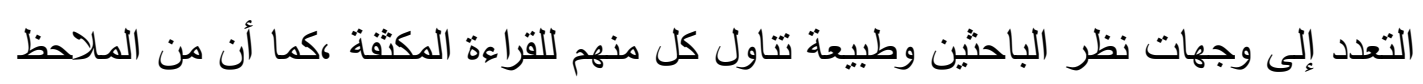
فى قوائم المهارات التي وردت فيما سبق، تكاد تتفق جميعا حول هدف واحد هو فهم القارئ

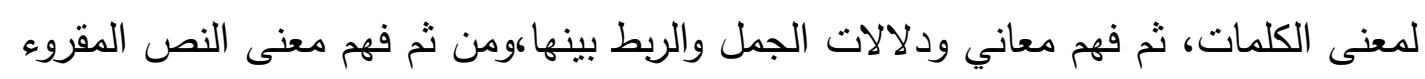

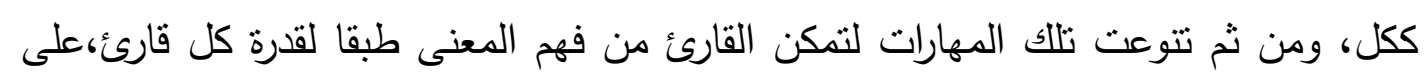

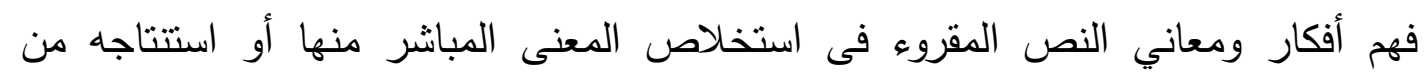
الأفكار والمعاني الضمنية فى النص،أو قدرته على ترتيب تللك الأفكار ثم نقدها وتذوقها والاستفادة منها فى ابتكار حلول لما بواجه القارئ من مشكلات ،ثم استخلاص الأفكار الرئيسية والفرعية وترتيب تلاك الأفكار ثم نقدها وفهها ،والإفادة منها فى القراءات المستقبلية . وسوف يستقيد البحث الحالي من مهارات تلاك القوائم وتوجهاتها في تحديد مستويات

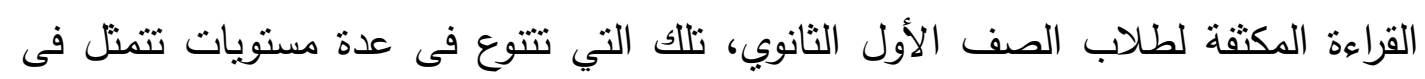
الفهم المباشر والاستتناجي والناقد والتذوقي و الإبداعي • r - r مهارات التفاوض

تقوم عملية التفاوض على مجموعة من الإجراءات التي ترتبط مع بعضها بحيث لا يمكن

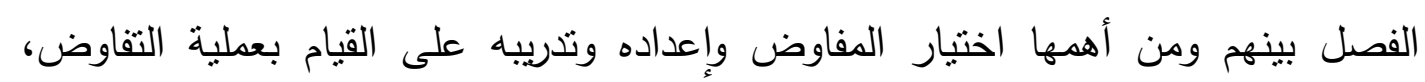
وتقويض ذلك الفرد للقيام بعملية التفاوض من أجل تحقيق الهدف من عملية التفاوض، ولذا واعنا

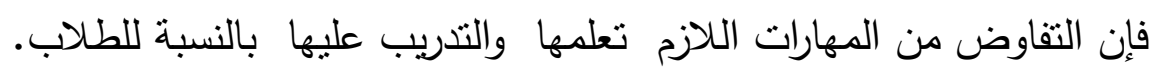

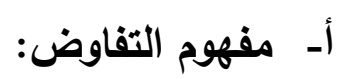

التفاوض سلوكيا عملية إيجاد الشروط التى يمكننا بواسطتها الحصول على ما نريد

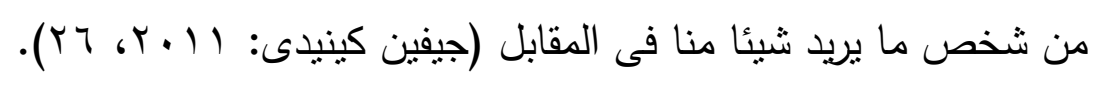

ويركز المعنى الاجتماعى للتفاوض على العلاقات بين الفئات الاجتماعية المنباينة، ولنضرب مثالا لذلك بمندوبين ترسلهم الدولة إلى المعاهد والكليات للتفاوض مع الثباب للعمل فى المناطق الجديدة مثل سيناء وتوشكي، وهؤلاء المندوبون سوف يواجهون 


\section{عدد يوليو

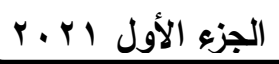

بمعارضين أثنداء من الثباب، ينقلون إليهم ما سمعوه عن تلك المناطق الجديدة من صعوبات ومشاكل فى الإقامة والمعيشة، ويكون على المندوبين أن يقنعوهم بالبراهين،

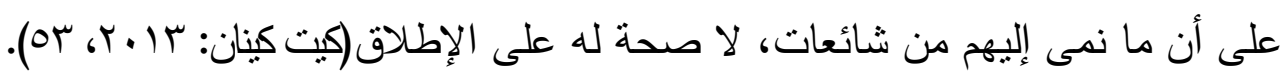

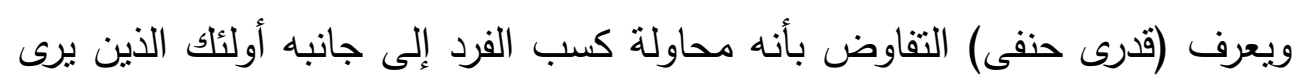
أن لديهم تحقيق مصلحة مادية أو معنوية له، ولكنهم لا يمنحونها له طواعية وليس بمقدوره

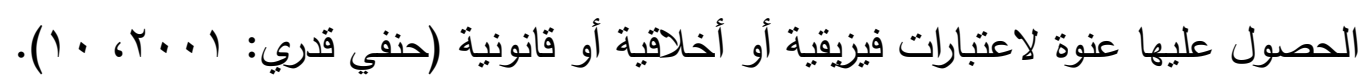
وعرف (عبد الرحمن ثابت) التفاوض بأنه عملية اجتماعية ونفسية ومنطقية تعتمد الاعندانه على التفاعل والتأثنر النفسى والإقناع والحث من خلال الحوار وتبادل وجهات النظر الهادفة بين طرفين أو اكثر لايهها تباين فى الآراء والأهداف التى يسعى كل طرف منها لتحقيقها وتتعلق بقضية أو خلاف أو مسألة معينة نرتبط مصالحها بها، بهدف التوصل إلى حل أو

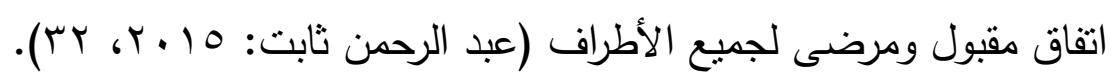
وهناك من عرف التفاوض بأنه تحرك إيجابي مشترك بين طرفين أو أكثر حول قضية من القضايا، يتم خلاله حوار ونقاش وتبادل للآراء للتقريب بين المواقف والموائمة بين

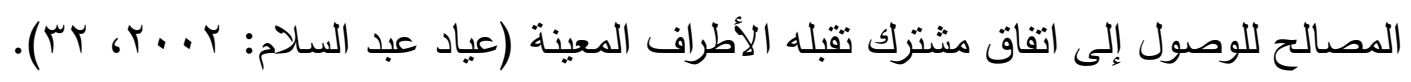

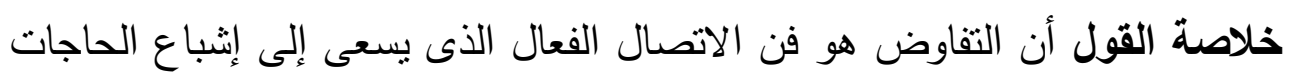
الإنسانية وإلى التواصل وتبادل الأفكار والآراء والمشاعر والمعلومات مع تتقيتها من مخاطر الأهر التحريف والتشويه، ويشكل عنصر الوقت عاملا ضاغطا على أطراف عملية التفاوض وبخاصة إذا كان هناك موعد نهائى وترتكز عملية التفاوض على العناصر التالية:

$$
\text { - صياغة وثقييم مصالح وأهداف الطرفين. }
$$

- محاولة التأثنر على إدراك الطرف الآخر للمصالح والهالح والأهداف.

$$
\text { - اتخاذ مواقف تفاوضية (عرض - قبول - اعتراض.....الخ). }
$$

والتفاوض فى أبسط معانية "أحد وسائل حل النزاعات وإدارة الصراعات الاجتماعية فردية كانت أم جماعية، دولية كانت أم قومية، وهناك أنواع وصور متعددة يلجأ الناس لتسوية منازعاتهم منل: المساومة، الوساطة، المساعى الحميدة، التفاوض، وكما أن عملية 


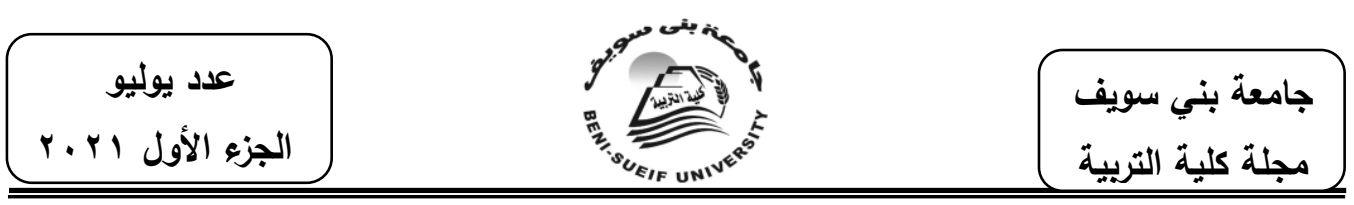

التفاوض فن يعتمد على الموهبة الذاتية، فهو أيضا علم حديث ترجع أصوله إلى الحضارة

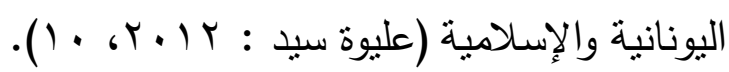

$$
\begin{aligned}
& \text { ب- مهارات التفاوض }
\end{aligned}
$$

هنالك مجموعة من المهارات التى يجب أن تتوافر فى الفرد الذى يقوم بعملية التفاوض وبجب تدريبه عليها حتى تصبح جزءا من شخصيته وثمة مجموعة من المهارات التى ينبغى

على الثخص المتفاوض التحلى بها نوجزها فيما يلى (Menkel:2010, 360) . ا- مهارة الأخذ والرد: من أهم المهارات التى يجب أن بتصف بها المتفاوض، مهارة

تبادل أطراف الحديث بالطريقة السليمة، فيكون محدد الفكر منضبط الكلام.

ץ- حضور البديهة: ومن المهارات الذهنية قدرة المفاوض على أن يلتقط المواقف

الطارئة فى المناقشات، وأن بتتاولها بالكلام والرد المباشر، دون أن يكون قد أعد

نفسه للرد عليها، لأنه لم يكن بعلم أن الموقف سوف بتطلب تتاولها والتعرض لها س- القدرة على استخدام الاكريات: ومن المهارات الذهنية أيضا التى ينبغى أن يتمكن منها المفاوض، القدرة على استخدام ما ترسب فى الذاكرة من أحداث ومواقف وأقوال

وتصريحات، وتاربخ متعاقب، يتعلق بالموضوع الذي بدور حوله التفاوض.

ـ- - التتاغم الوجدانى مع المتفاوضين: ومن المهارات التي تلعب دوراً مهمًا فى أثناء المفاوضات، خفة الظل، والبراعة فى استخدام النكتة، ولكن بشرط ألا يتحول

$$
\text { المفاوض إلى شخص كوميدى. }
$$

ه- تحديد الهدف الرئيسي والأهداف الفرعية من التفاوض: من المهارات التى يجب أن يتسلح بها المتفاوض القدرة على تحديد الهدف الرئيسي من المفاوضات، بالإضافة

$$
\text { إلى الأهداف الفرعية، أو المرحلية. }
$$

ج- حسن السير والسلوك: فالمفاوض يجب أن يكون حسن السير والسلوك، ولا تلعب به الأهواء فيصير عرضة لأخذ الرشاوى، ولا يكون شديد القابلية للإيحاء. 


\section{عدد يوليو

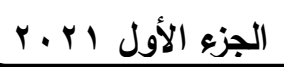

- - المرونة والقابلية للتطور واكتشاب الخبرات الجديدة: فالمفاوض يجب أن يكون شخصية مرنة، وقابلة للتطور مع المتطلبات الحضاربة ولا يكون مغلقا على فكر

$$
\text { ضيق، يلتزم بـه مهما تغيرات الظروف والأحوال. }
$$

1- القدرة على التأثير والإقناع: فكلما كان المفاوض على درجة عالية من التأثير فيمن يتتاقش معهم، وعلى مستوى رفيع من الإقناع بالمنطق السديد، وبتقديم الحجج الدامغة فإنه يكون بالتالى قادرا على النجاح فى مهامه التفاوضية، وبتطلب من المتفاوض أن يتصرف بكياسة وأخلاق عالية لأن مهمة المتفاوض هى أن يختار

أيسر الطرق وأسهلها للوصول إلى الغاية التى يهدف إلبها .

ج- شروط التفاوض:

للتفاوض شروط يجب الأخذ بها، فيجب أن نعترف أن عامل الرغبة بعد من أصعب العوامل التى يجب التحكم فيها لشموله على مجموعات شتي من العناصر غير الملموسة، والتى يجب على المتفاوض أن بلتزم بها أثناء عملية التفاوض لتحقيق الهدف من القيام

بعملية التقاوض ومن تلك الثروط ما يلى:( (Stuchlmachar \& Shampage:2010, 481). ا- - القوة التفاوضية: ترتبط القوة التفاوضبة بعدة جوانب تبدأ أهمها بحدود أو مدى السلطة والتفويض الذى تم منحه للفرد المفاوض واطار الحركة المسموح له بالسير فيه

$$
\text { وعدم تعديه أو اختراقه فيما بتصل بالموضوع • }
$$

ب- المعلومات التفاوضية: وهى من أهم الثروط التى يجب ثوافرها فى عملية التفاوض حيث إن أي عملية تفاوض ناجحة تحتاج إلى توافر كم مناسب من البيانات

$$
\text { والمعلومات، سواء عن القضية أو الموضوع محور التقاوض. }
$$

ب- القدرة على التفاوضية: يتصل هذا الثرط أساساً بأعضاء الفريق المفاوض، ومدى

$$
\text { البراعة والمهارة والكفاعة التى يتمتع بها أو يحوزها أفراد هذا الفريق هُهاء }
$$

ع- الرغبة المشتركة: وبتصل هذا الثرط أساساً بتوافر رغبة حقيقية مشتركة لدي الأطراف هرة المتفاوضة لحل مشاكلها أو منازعاتها بالتفاوض، واقتتاع كل منهم بأن التفاوض هو الوسيلة الوحيدة أو الأفضل لحل هذا النزاع. 


\section{عدد يوليو

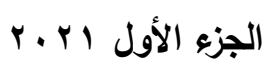

- - المناخ المحيط: يجب العمل على توفير المناخ المناسب للبدء بالعملية التفاوضية، أو المضي قدما فى سبيل حلها أو الوصول إلى نقاط اتفاق بشأنها تمهداً لإقامة العلاقة أو توصل للهدف المنشود المتعين تحقيقه والوصول إليه.

با

إن إستراتيجية خلية التعلم هي إحدى إستراتيجيات التعلم النشط، والتي تركز في الأساس على تذكية روح التعاون بين المجموعة الواحدة ومع المجموعات الأخرى ، ولهذا فان أحد المخرجات المهمة والرئيسية عند استخدامها في التذريس هو ظهور تعلم تعاوني بين المجموعات لاستيعاب موضوعات الموقف التعليمي وكذللك تعلم نشط وفاعل يعزز من مكانة الطالب ودوره المحوري في عملية التعلم والتعليم ( محمد الأسطل: . . Y، V). ويعرفها (Kish, et al: 2005 , 98 ) بأنها عبارة عن التعلم الذي يتم بين شخصين يعمالن معا وجها لوجه بحيث يشعر كل منهم بأنه عضو في المجموعة تسعى لتحقيق الأهداف التي كلفوا بها. في إستراتيجية خلية التعلم يقوم المدرس بتقسيم طلاب الصف الواحد إلى مجموعات ثنائية كل مجموعة يتم تشكيلها من طالبين إذ يقوم أحد الطالبين بطرح السؤال أو النشاط المطلوب ويقوم الطالب الثاني في المجموعة الثنائية بالإجابة عن السؤال أو النشاط المذكور أو يفكر الطالبان معا ليتوصلا إلى نتيجة واحدة يتفقان معا على صياغتها بالطريقة التي تمنل تفكيرهما، ثم يتم عرض النتيجة على باقي المجموعات الثنائية الأخرى ومناقشتها وكذللك تقوم المجموعات الثنائية الأخرى في الصف بهذا الدور، وفي أثناء ذلك يقوم المدرس بالتحرك داخل الصف لتقديم الدعم للمتعلمين في كل المجموعات من حيث الرد على أسئلة

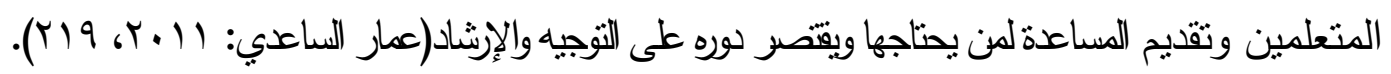

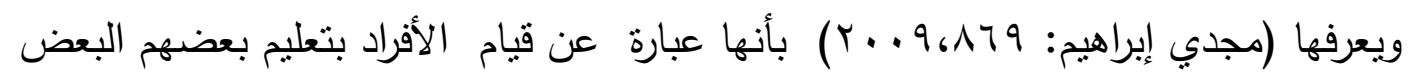
كأن يقوم بعض الطلاب بتعليم من هم أقل منهم في تحصيل بعض جوانب المادة الدراسية وفهم أساسياتها. 


\section{عدد يوليو

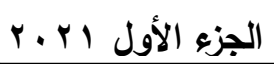

إن هناك عددا متزايدا من التربوبين والمدرسين والمعلمين والباحثين المتحمسين لهذه الإستراتيجية بوصفها إستراتيجية تدريسية ضرورية لتلعيم التعلم النشط والفعال في مختلف المجالات الاكاديمية وبوصفها تساعد المتعلم على التفكير والحفظ واستتفاء المعلومات والخبرات والمهارات (Lyons: 2010 (90) - - خطوات إستراتيجية خلية التعلم

هناك عدة خطوات يمكن اتباعها عند استخدام إستراتيجية خلية التعلم وهي: - يقوم الطلاب بقراءة موضوع الدرس مسبقا قبل موعد الدرس وتحفيزه. - - تتظيم الطلاب في صورة أزواج بحيث بجلس كل طالبين معا على منضدة واحدة أو على مقعدين متجاورين وفقا لإمكانات وأثاث حجرة الدرس. - يقوم الطالب الأول وبرمز لله برمز (أ) بالقاء السؤال الأول على الطالب الثاني ويرمز له بالرمز (ب) وعليه أن يجيب في صورة شفهية أو كتابية.

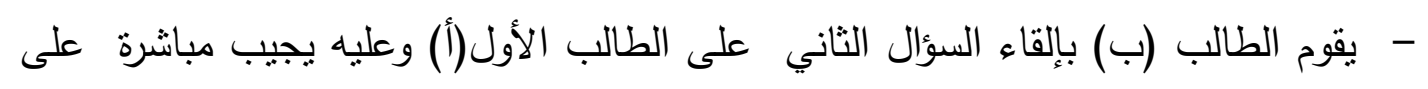
المهمة العملية التي تدور حولها الأسئلة. - يستمر تبادل الأسئلة بين الطلاب حتى الانتهاء من الأسئلة المحددة. - - أثناء تبادل الطلاب الأسئلة والأجوبة على المدرس المرور بين الطلاب لملاحظة الأداء من جانب الطلاب وتوجيه و إرشاد الطلاب أثناء الأداء وتوفير التغذية الراجعة على العمل وتقبل الإجابات الصحيحة.(فاطمة الزايدي : 9 . . . ، ، ع ) ثانيا: مشكثة البحث استشعرت الباحثة وجود مشكلة البحث من خلال العرض السابق لبعض الدراسات السابقة ، بالإضافة أن تلاك الدراسات خلصت إلى أن المعلمين يركزون على الجوانب المعرفية كالفهم ، والاستيعاب ، والمعجم اللغوي وعدم إعطاء مهارات القراءة المكثةة (مستوى الفهم المباشر - الفهم الاستنتاجى - مستوى الفهم الناقد - مستوى الفهم التذوقي - مستوى الفهم الابتكارى ) القدر الكافي من الاهتمام ، وسيرهم في طربقتهم على نمط معتاد في التدريس لا يشجع على فاعلية الطلاب داخل الصف ، ولا يشجع على حب المادة ، وكذلك 


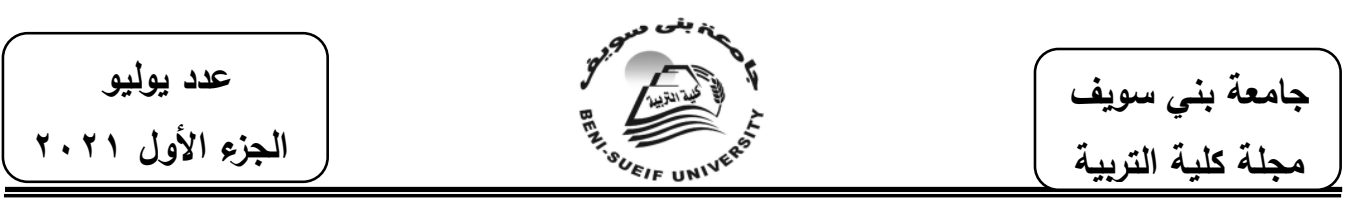

وجود قصور لدي الطلاب في مهارات التفاوض ( التروي في اتخاذ القرار - الانسحاب بلطف -المشاركة - التذرج ) ويؤكد هذا ما قامت به الباحثة في الدراسة الاستطلاعية ، حيث قامت بإجراء مقابلات شخصية - محددة الهدف - مع عدد من معلمي اللغة العربية وموجهيها ، وتضمنت المقابلة سؤلين حول : الطريقة المتبعة في التدريس؟ ، وهل يهتم

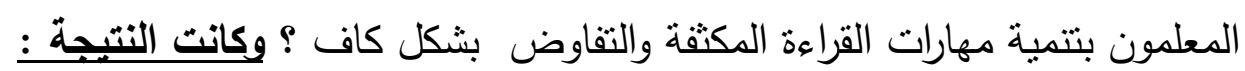
اتفاق نسبة كبيرة من الموجهين - بلغت 70 \% - على ميل المعلمين في تدريسهم إلى اتباع الطرق المألوفة ، والتي تعتمد على الثرح والتلقين من جانب المعلم ، والتركيز على الجوانب

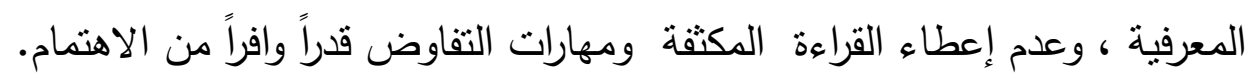

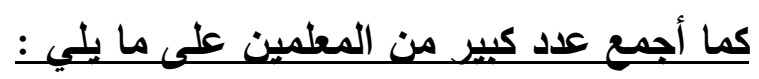
ا - - اتباع معظمهم الطرق التقليدية في تدريس المحفوظات. r- اتفق رأى الموجهين مع ما قاله المعلمون في خطوات تتاول المحفوظات.

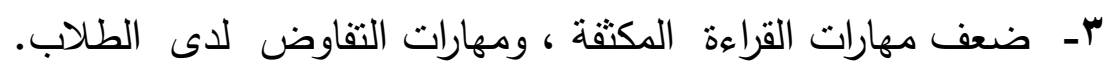
تحديد مشكلة البحث

انطلاقاً مما سبق تتمنل مشكلة البحث في : ضعف طلاب الصف الأول الثانوي مهارات القراءة المكثفة ومهارات التفاوض بسبب اتباع المعلمين للطربقة التقليدية في التدريس ، ومن هنا تبرز الحاجة إلى أساليب تدريسية منطورة ، تجعل حصة القراءة أكثر فائدة ، وتشويقاً ، ومتعة ، وتعطي اهتماماً بالقراءة المكثقة والتفاوض، وبالتالي فإن مهمة هذا البحث

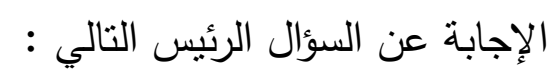
ما فاعلية استخدام خلية التعلم في تتمية مهارات القراءة المكثفة ومهارات التقاوض لأى طلاب المرحلة الثانوية؟ ماته

\section{ويتفرع من هذه السؤل التساؤلات الفرعية التالية :}

ا - ما مهارات القراءة المكثفة المناسبة لطلاب الصف الأول الثانوي ؟

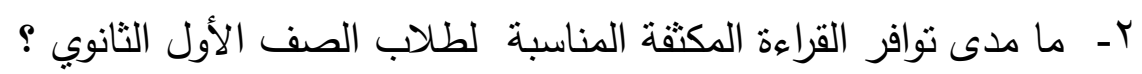
r- ما فاعلية استخدام خلية التعلم في تتمية مهارات القراءة المكثة لدىطلاب المرحلة الثنانوية؟ 


\section{عدد يوليو

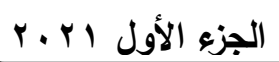

ع- ما مهارات التفاوض المناسبة لطلاب الصف الأول الثانوي؟

○ـ ما مدى توافر مهارات التفاوض المناسبة لطلاب الصف الأول الثانوي؟ T- ما فاعلية استخدام خلية التعلم في تتمية مهارات التفاوض لاى طلاب المرحلة الثانوية؟

ثالثا: أهمية البحث قد يفيد هذا البحث: أ -الطلاب

- يسهم فى تحديد أنسب مهارات القراءة المكثقة، ومهارات التفاوض الملائمة لقدرات طلاب الصف الأول الثانوي. - يسهم استخدام خلية التعلم في إكساب الطلاب روح التعاون والمودة.

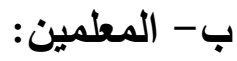
- توجيه أنظار معلمي اللغة العربية إلى فعالية استخدام خلية التعلم فى تتمية مهارات اللغة

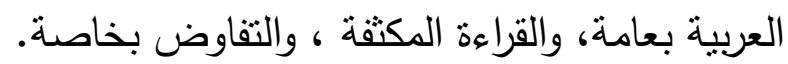

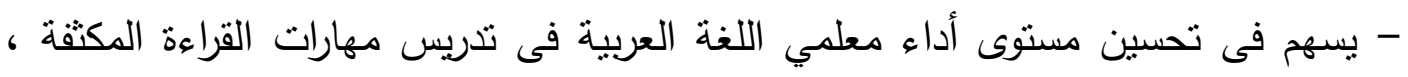
ومهارات التفاوض فى المراحل الدراسية المختلفة بوجه عام، وتلك من خلا تطيقهم خلية التعلم - يسهم في زيادة وعى المعلمين بطبيعة القراءة المكثفة، ومهاراتها؛ مما يساعدهم فى سهولة تدريسها وتعليمها.

- يعكس أهمية دور المعلم وأساليب التعليم والتعلم فى إنجاح العملية التعليمية، مما يلفت

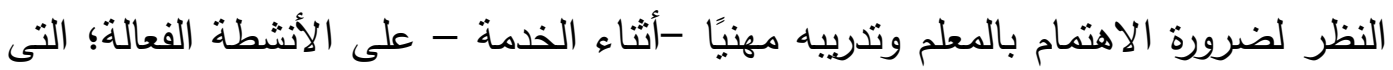
تتمى مهارات القراءة المكثفة .

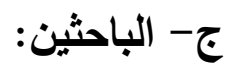

- يفتح هذا البحث المجال أمام الكثثر من البحوث والدراسات المشابهة فى مجال القراءة المكثقة ومهاراتها المتعددة. - يفتح المجال لبحوث ودراسات أخرى يمكن أن تثتاول تعليم اللغة العربية باستخدام الأنشطة فى مراحل التعليم كافة. 


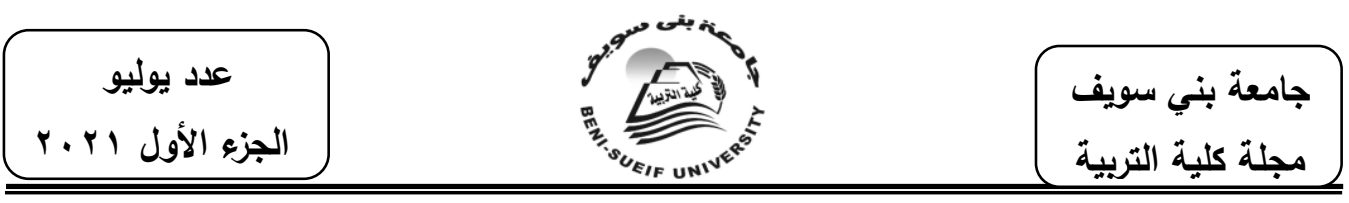

د - مخططى مناهج اللغة العربية:

- يسهم فى توجيه نظرهم إلى مهارات القراءة المكثقة ، ومهارات التفاوض وضرورة تتميتها. تطوير الأساليب والأنشطة المستخدمة فى تتمية مهارات القراءة المكثقة لدى هؤلاء الطلاب. - إعداد أدلة المعلم فى ضوء الأساليب والأنشطة لتحقيق مهارات القزاءة المكثة، ومهارات الثقاوض. رابعا: أهداف البحث

1- تصميم قائمة لمهارات القراءة المكثفة المناسبة لطلاب الصف الأول الثانوي • r- التحقق من مدى توافر القراءة المكثفة المناسبة لطلاب الصف الأول الثانوي .

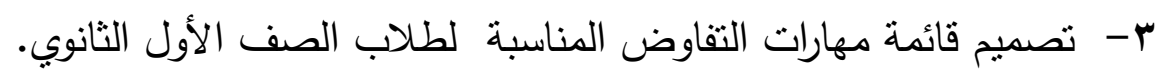
ع - التحقق من مدى توافر مهارات التفاوض المناسبة لطلاب الصف الأول الثانوي. ه- التحقق من فاعلية استخدام خلية التعلم في تتمية مهارات القراءة المكثفة ومهارات التفاوض لدى طلاب المرحلة الثانوية. خامسا : الاطار العملي : 1 - منهج البحث وإجراء|ته: :

يعتمد هذا البحث على التصميم التجريبى القائم على مجموعتين :المجموعة الأولى مألى تجريبية درست موضوعات دليل المعلم القائم على استخدام خلية التعلم في تتمية مهارات القراءة المكثفة ومهارات التفاوض لدى طلاب المرحلة الثانوية ، والمجموعة الثانية ضابطة درست نفس الموضوعات بالطريقة التقليدية المعتادة وهى قم - اقرأ - أجلس، وهذه الطريقة التقليدية هي التي نراها الباحثة مستخدمة فى المدارس -في حدود علم الباحثة-، وهذا التصميم يفيد في تحديد مدى فاعلية استخدام خلية التعلم. r

تم اختيار فصلين من فصول الصف الأول الثانوي بمدرسة باروط الثانوية ، بمحافظة بني

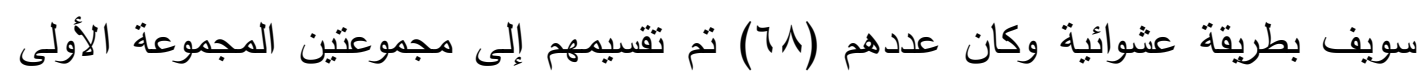

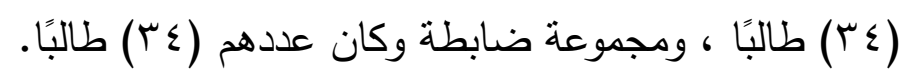




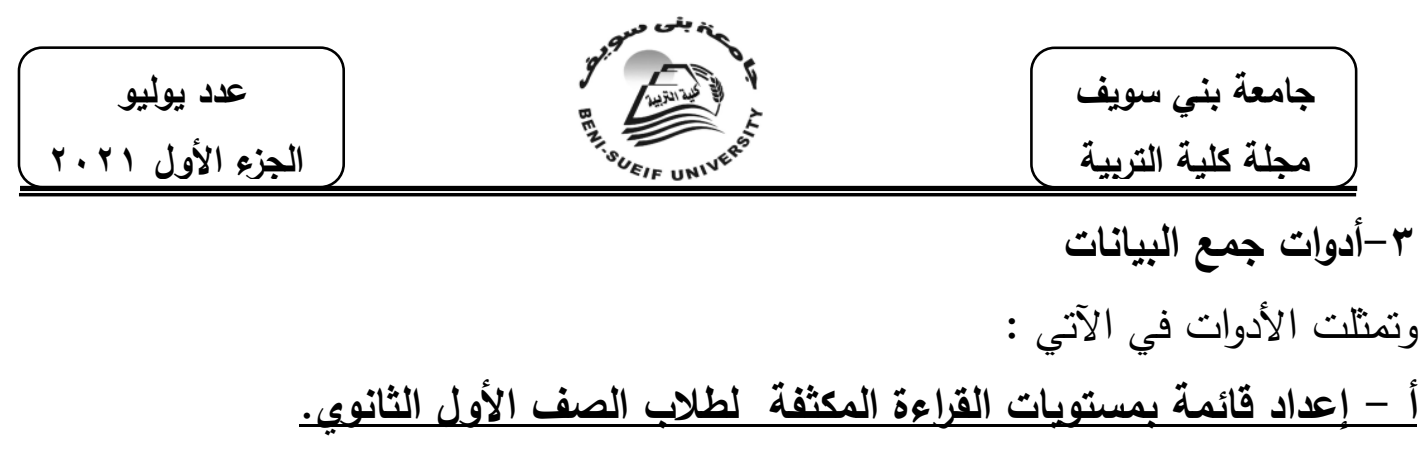

الهرف من القائمة: تهذف هذه القائمة إلى : تحديد مستويات القراءة المكثفة المناسبة

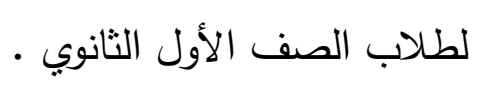

مصادر بناء القائمة : توصلت الباحثة لتحديد مستويات القدرة القرائية المناسبة

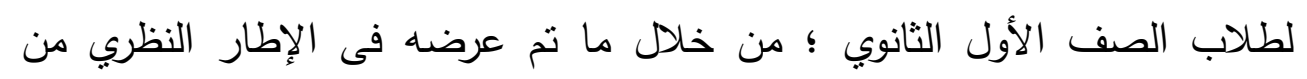
البحث الحالي ومن خلال ذلك تم التوصل إلى تحديد خمسة مستويات للقراءة المكثقة

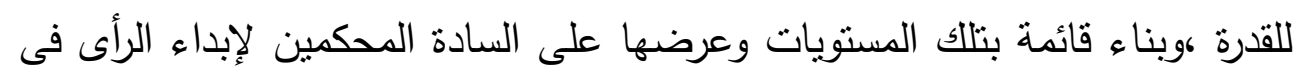
مدى مناسبتها لطلاب الصف الأول الثانوي (انظر قائمة المحكمين على قائمة

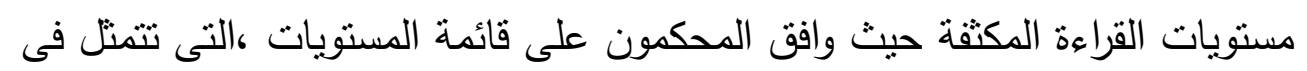
المستويات الآتية ( مستوى الفهم المباشر - مستوى الفهم الإستنتاجى - مسنوى الفهر الناقد- مستوى الفهم التذوقي - مستوى الفهم الابتكارى) ب- إعداد اختبار لتقويم مستويات القراعة المكثفة لطلاب الصف الأول الثانوي: بعد التوصل إلى مهارات القراءة المكثفة المناسبة لطلاب الصف الأول الثانوب ،وخروج البحث الحالي، قامت الباحثة بإعداد اختبار لقياس أداء طلاب الصف الأول الثانوي العام في

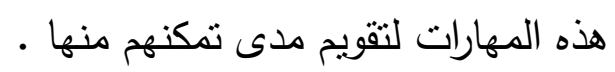

وسوف يتم عرض الخطوات التي اتبعت في بناء هذا الاختبار فيما يلى :

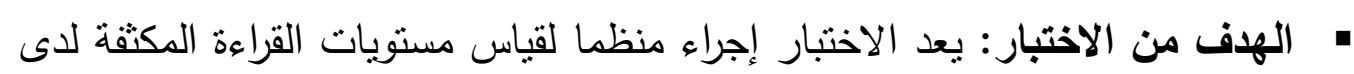

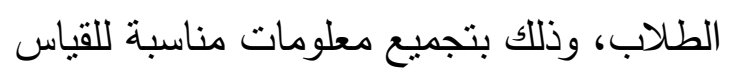
مصادر إعداد الاختبار: تم إعداد هذا الاختبار بالاعتماد على عدد من المصادر المتتوعة والتي تمنلت في دراسة الباحثة كتب القياس والتقويم التربوي وكتابات المتخصصين فى إعداد الاختبارات بأنواعها وذلك فيما يتعلق بالقواعد والثروط لئه

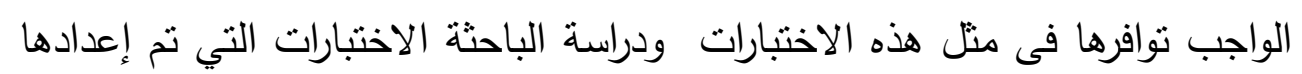




\section{عدد يوليو

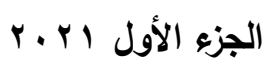

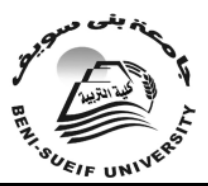

جامعة بني سويف مجلة كلية التربية

في الدراسات السابقة ، واستفاد منها في إعداد الاختبار الخاص بهذه الدراسة ومنها

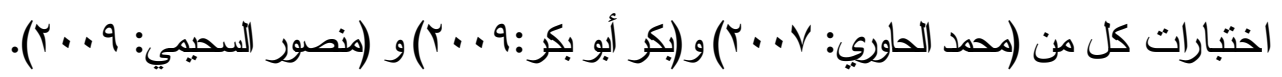
تحديد محتوى الاختبار: تم بناء الاختبار في البحث الحالي في ضوء ما تم تحديده

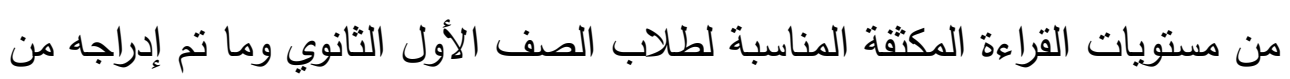

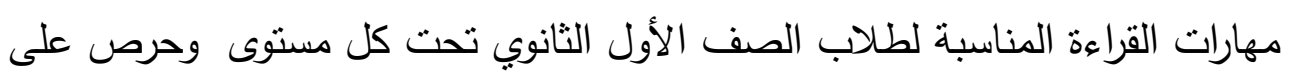
أن يكون محتوى الاختبار من النصوص والموضوعات القرائية المقررة على الطلاب في الفصل الدراسي الثاني لمناسبتها لأعمار وخصائص الطلاب وباعتبار أنها خبرة

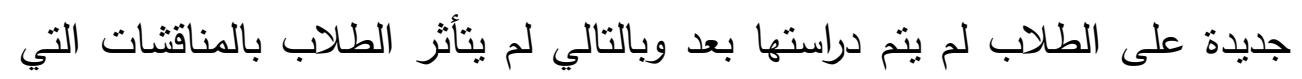

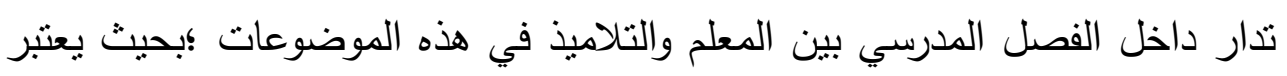
كل موضوع من موضوعات الاختبار خبرة جديدة وموقفا جديدا بالنسبة للطلاب .

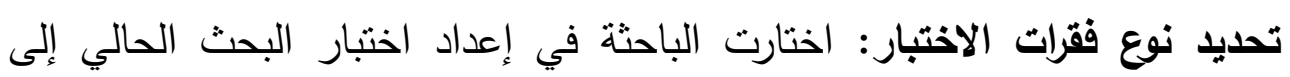
اختيار نمط الاختيار من متعدد لما له من فوائد ؛حيث يمنل أكثر الاختبارات شيوعا واستعمالا في قياس القدرات والمهارات القرائية كما أن هذا النمط من أنماط أسئلة الاختيار من متعدد يتميز بمميزات تؤكد اختياره كنمط لهذا البحث تتمنل في عينة كبيرة في وقت قصير وهذا ما يتفق مع توجه البحث الحالي ومنهجه حيث انه دراسة مسحية لعينة كبيرة تمثل المجتمع الأصلي للعينة وتحتاج إلى أداة لقياس هؤلاء الطلاب تتسم بالسهولة في التطبيق والتصحيح وهذا ما بيقق مع نمط الاختيار من متعد. صياغة فقرات الاختبار: التزمت الباحثة فى صياغتها لفقرات الاختبار المستخدم فى بـ هذا البحث باختيار الإجابة الصحيحة من بين عدة إجابات إحداها صحيح والباقي خطأ وتتنمل كل فقرة من هذا النمط على مقدمة، وإجابات محتملة (البدائل) التي لئحن تتضمن إجابة واحدة فقط، والخطوات التي اتبعتها الباحثة لصياغتها لمفردات الاختبار هي كالتالي : التهابه بناء الاختبار: بعد أن قامت الباحثة بالإجراءات والخطوات السابقة فى إعداد

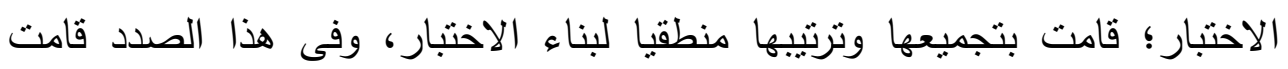




\section{عدد يوليو

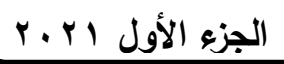

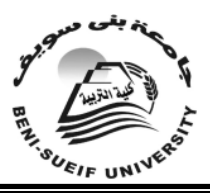

جامعة بني سويف

مجلة كلية التربية

الباحثة بمراعاة وضوح تعليمات الاختبار فى مقدمة الاختبار من حيث بنط الخط والتتسيق والكتابة والتوزيع المنطقي للفقرات. والتوزيع العشوائي للبدائل.

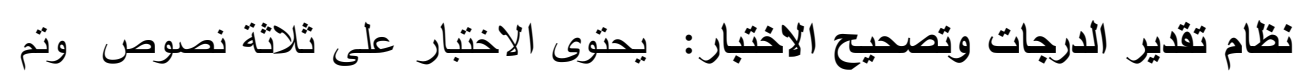
تقدير(Y) درجة لكل سؤال ؛ يحصل عليها الطالب الذي أجاب على السؤال إجابة صحيحة، ويحصل الطالب على درجة (صفر) إذا أجاب إجابة خاطئة ،ويستبعد السؤال المتروك،وكذلك اختيار الطالب لأكثر من بديل من بدائل الإجابة ،ثم تجمع درجات كل طالب وذللك لتحديد الدرجة الكلية التي حصل عليها الطالب فى الاختبار

،والتي ستستخدم لتحديد مستواه طريقة التصحيح : اختارت الباحثة طريقة المفتاح الثفاف ،حيث تعد طريقة سريعة ودقيقة فى التصحيح ،كما أنها مناسبة للبحث الحالي حيث تكثر أوراق إجابات الطلاب طبقا لكثرة العينة المستخدمة واتفاقها مع منهج الدراسة الحالية كدراسة مسحية تستلزم عينة كبيرة من الطلاب ؛ و تقوم فكرة هذه الطريقة على تسجيل الإجابات الصحيحة على ورقة شفافة أو شريحة شفافة ،ثم يكتب مفتاح الإجابات عليها كصورة طبق الأصل لورقة إجابة الطالب، ثم يتم مطابقة الثربحة الثفافة بورقة إجابة الطالب وذلك لمقارنة إجابات الطالب بمفتاح الإجابة المعد على الثريحة الثفافة،وبذلك يم تقدير درجة الطالب فى الاختبار بدقة وسرعة. • عرض الاختبار عل مجموعة من المحكمين: بعد أن قامت الباحثة بوضع الاختبار فى صورته الأولية قامت بعرضه على مجموعة من المحكمين،وهم من المعلمين

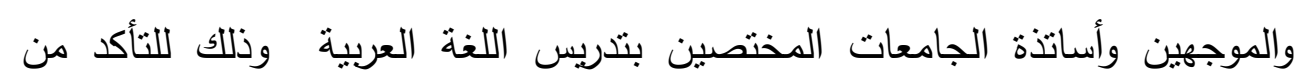
صلاحية الاختبار للنطبيق. تحديد زمن الاختبار: تم تحديد زمن الاختبار بحساب الزمن الذي استغرقه أسرع

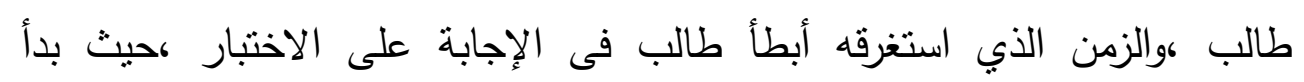

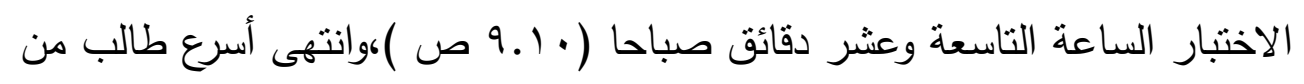

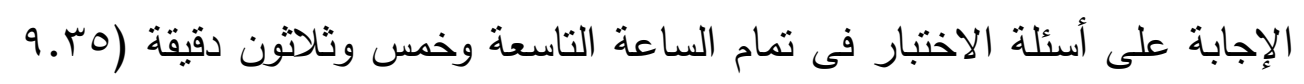




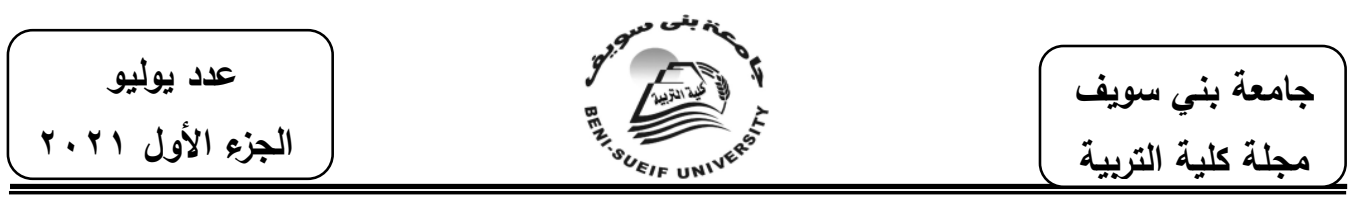

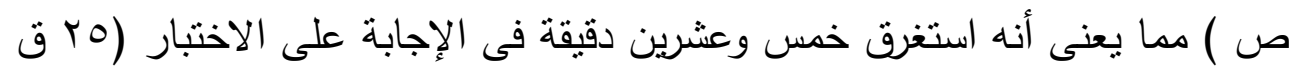

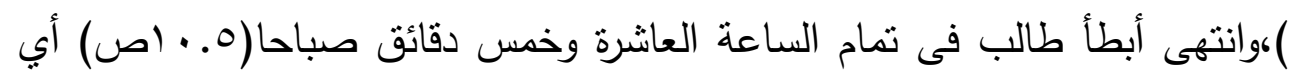

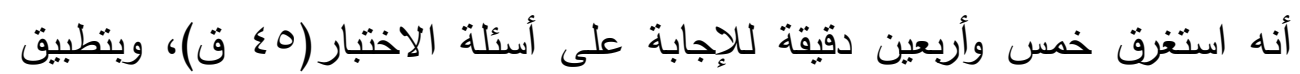
المعادلة التالية لحساب منوسط زمن الاختبار : هبات الاختبار : وكان معامل الثبات طبقا لما أسفرت عنه نتائج النطبيق على الثئل

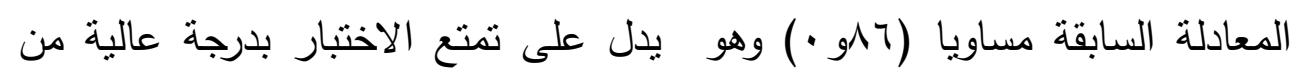
الثبات تمكن من استخدامه فى البحث الحالي باطمئنان. ج- استبيان التفاوض للإجابة على أسئلة البحث صممت الباحثة اسنتيانًا، كأداة لجمع البيانات اللازمة. وقد تكونت من

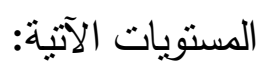
- مهارة جمع البيانات وتحليل واستخدام المعلومات(0) فقرات

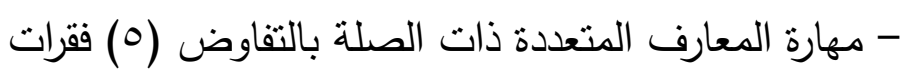

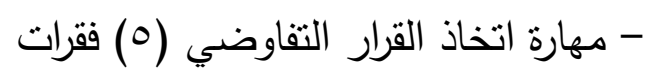

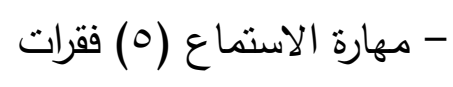

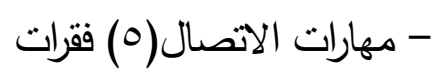

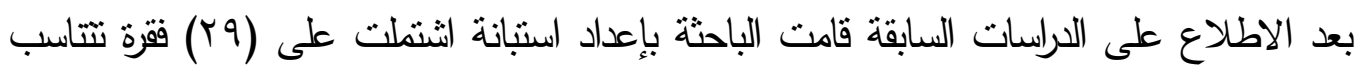

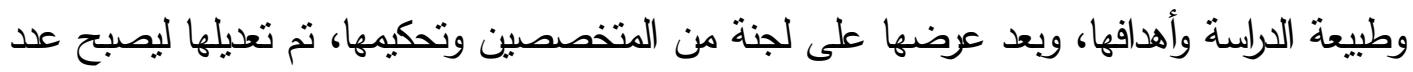

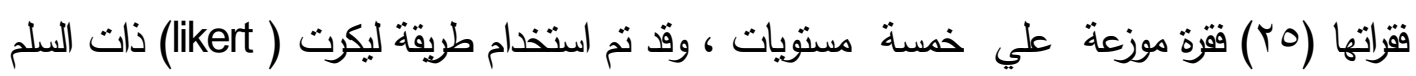

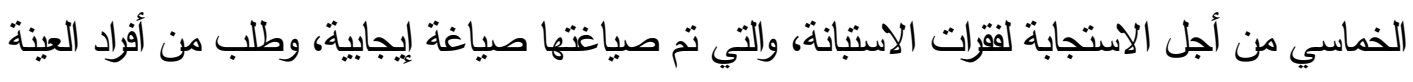

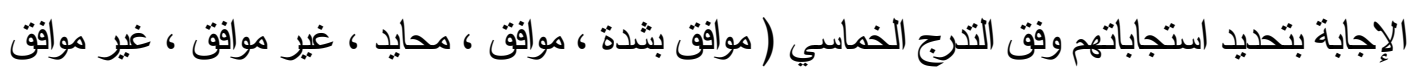

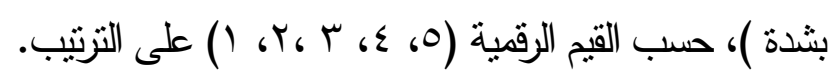

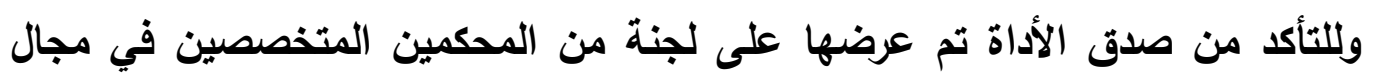

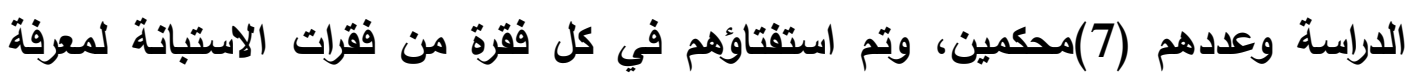

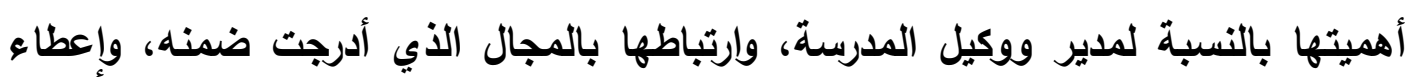


الرأي في التعديل أو الحذف، أو إضافة فقرات أخرى. ويعد استلام استجابات المحكمين السبعة، تم الأخذ برأي الأغلبية منهم، وأعيدت صياغة الاستبانة في الصورة النهائية

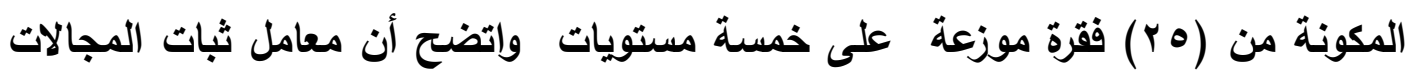
في أداة البحث أعلى من ^.. . . ويناء على هذه النتيجة فإن مستوى الثبات لمحتوى الأداة يعد ملائما من وجهة نظر البحث العلمي. د - برنامج تعليمي قائم على استخدام خلية التعلم • أسس بناء البرنامج : بعد الاطلاع ، وكخلاصة من الإطار النظري توصلت الباحثة

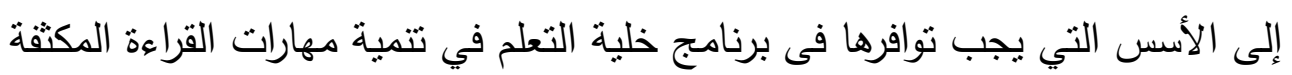

ومهارات التفاوض لاى طلاب المرحلة الثانوية حيث تشمل ما يلي :

- الخبرات والمهارات السابقة لطلاب الصف الأول الثانوي. - مراعاة خصائص الطلاب العمرية . - التجديد الدائم في الوسائل التعليمية لكي تتتاسب مع دروس البرنامج وعمر الطالب - احتواء البرنامج على تعزيزات ومواقف لإثارة حب الإنظلاع وتنمية الملاحظة لدى الطلاب . - أن يساعد أسلوب التقويم المتبع في نهاية البرنامج على قياس فاعلية استخدام خلية التعلم في تتمية مهارات القراءة المكثفة ومهارات التفاوض لدى طلاب المرحلة الثانوية. أهداف البرنامج : يهدف البرنامج إلى نتمية مهارات القزاءة المكثة ومهارات الثفاوض. خطوات بناء البرنامج: تم إعداد برنامج تتمية مهارات القراءة المكثفة ومهارات

التفاوض. وفقاً للخطوات التالية:

الخطوة الأولى: تحديد الأهداف التعليمية

الخطوة الثانية: تحديد المحتوى

الهدف الأساسي من دراسة البرنامج هو تتمية مهارات القراءة المكثفة ومهارات التفاوض وقد

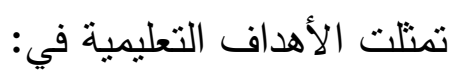
أولا: مهارات القراءة المكثقة 


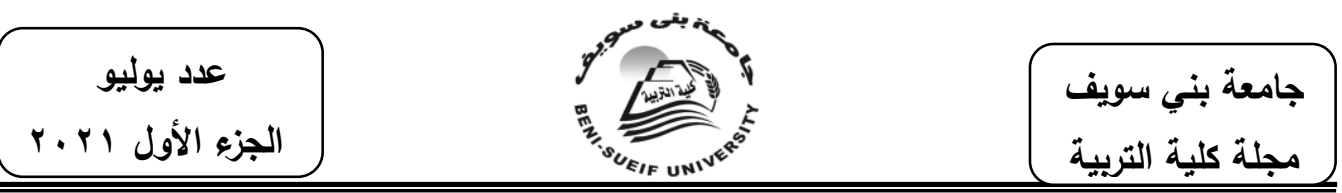

$$
\begin{aligned}
& \text { - الفهم الاستنتاجى. }
\end{aligned}
$$

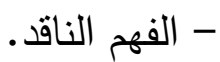

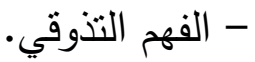

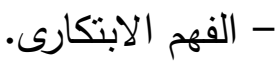

$$
\begin{aligned}
& \text { ثانيا: مهارات التفاوض } \\
& \text { - مهارة جمع البيانات وتحليل واستخدام المعلومات. } \\
& \text { - مهارة المعارف المتعددة ذات الصلة بالتفاوض. } \\
& \text { - مهارة اتخاذ القرار التفاوضي. }
\end{aligned}
$$

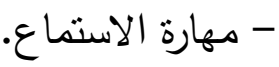

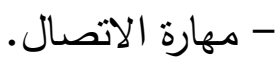

حيث تتضمن كل مهارة أساسية مجموعة من المهارات الفرعية التى تقع تحت مسماها كما وضحتها الباحثة عند تحديد أبعاد اختبار مهارات القراءة المكثفة. الخطوة الثالثة : إعداد الوسائل التعليمية اللازمة للتدريس لتحقيق الأهداف التعليمية الخاصة بكل درس قامت الباحثة بتوفير مجموعة من الوسائل التعليمية والتي نتتمل على مواد تعليمية تستخدم فى تتفيذ الأنشطة الخاصة بكل درس، ومن

$$
\text { الأدوات المستخدمة فى البحث الحالي : }
$$$$
\text { ورقة عمل لكل مهارة متضمنة فى الدرس. }
$$

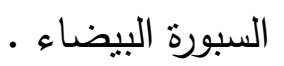

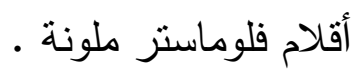

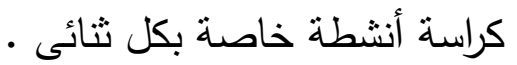$$
\text { كراسة أنشطة خاصة بكل طالب. }
$$

الخطوة الرابعة : توفير التجهيزات المدرسية والتتظيم الداخلي لها ويقصد بالتجهيزات أن بتأكد

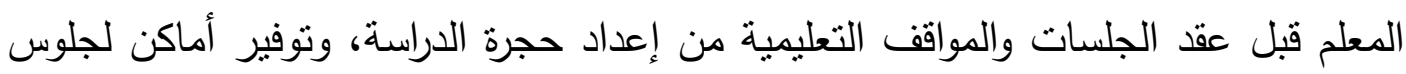
جميع التلاميذ فى صورة ثنائيات بحيث يكون كل مقعد يجلس عليه قرين معلم وزميله المتعلم، 


\section{عدد يوليو}

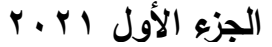

وتوفير الوسائل التعليمية المناسبة لكل درس ، وأماكن لحفظ الأدوات بعد انتهاء العمل، وتزويد كل مقعد بالأتى : أوراق عمل الطلاب معاً ، كراسة النشاط الخاصة بكل ثنائى ، كراسة النشاط الخاصة بكل طالب.

الخطوة الخامسة: إعداد جلسات البرنامج : وقد بلغ عدد جلسات البرنامج (0) جلسات تعليمية ، في (0) أسابيع بواقع حصنين أسبوعياً ، حيث يتم فى كل جلسة تتمية مهارة من مهارات القراءة المكثقة ، ومهارة من مهارات التفاوض كما يلي :

\begin{tabular}{|c|c|c|c|c|}
\hline وسائل التدريب & هدف التدريب & \multicolumn{2}{|l|}{ المحتوى } & الأسبوع \\
\hline & التفاعل بين الطلاب & \multicolumn{2}{|l|}{ تمهيد } & 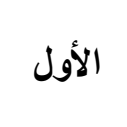 \\
\hline & & مهارة التفاوض & القراة المكثفة & \\
\hline \multirow{5}{*}{\multicolumn{2}{|c|}{ التفاعل بين الطلاب وبين الباحثة }} & مهارة جمع البيانات وتحليل & الفهم المباشر & 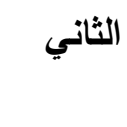 \\
\hline & & ذات الصلة بالتفاوض المعارف المتعددة & الاستنتاجى الفهم & 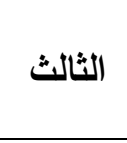 \\
\hline & & مهارة اتخاذ القرار & الفهم الناق & 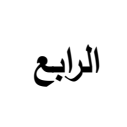 \\
\hline & & مهارة الاستماع. & القهم التذوقي & 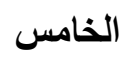 \\
\hline & & مهارة الاتصال & الفهم الابتكارى & السادس \\
\hline
\end{tabular}

وقد صممت كل جلسة من الجلسات السابقة على الوجه التالي الأهداف الإجرائية، الوسائل التعليمية، الخطوات المتبعة في التدريس وتتضمن ( التمهيد وتتويع المثيرات )، التقويم، الواجب المنزلي، مناقنة الإيجابيات والسلبيات . 


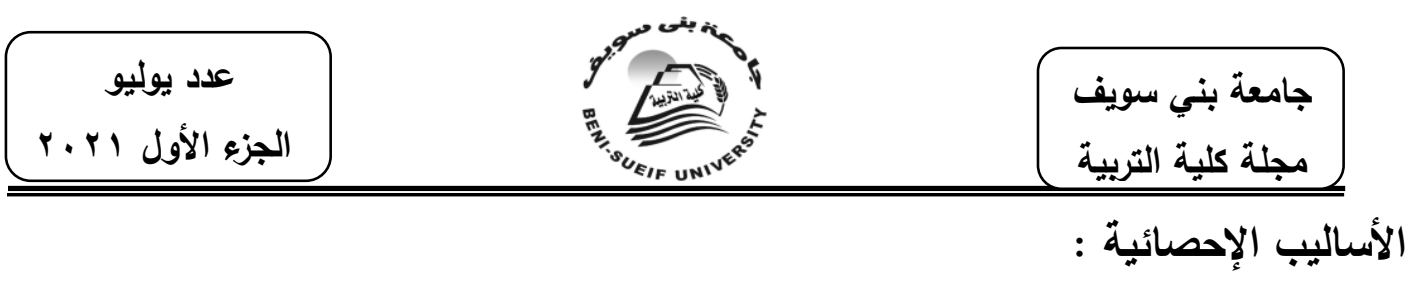

تم استخدام مجموعة من الأساليب والمعالجات الإحصائية المناسبة ويمكن تلخيصها على الإسى النحو التالي : (الن أ-النسبة المئوية: وذلك لتحديد نسبة الذين وصلوا أو تخطوا حد الإتقان والذين لم يتخطوه إلى العدد الكلى لعينة الدراسة ،وكذلك النسبة المئوية لدرجة صعوبة كل فقرة على الاختبار المعد للاراسة الحالية. ب- اختبار(ت) (T-Test) :وذللك لدلالة الفرق بين متوسطي أداء الطلاب والطالبات على اختبار القدرة القرائية. ج- حساب التكرار: وذللك لحساب درجات طلاب العينة فى الاختبار المستخدم فى الدراسة الحالية فى ضوء معيار الأداء للقراءة الناضجة. سادسا : نتائج البحث: يهدف هذا المحور إلى عرض النتائج التي توصلت إليها الباحثة بعد نطبيق البحث على

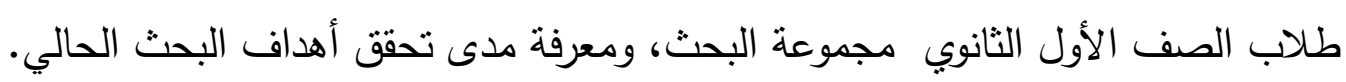
وفيما يلي عرض تقصيلي لذلك: أولا :النتائج المتعلقة بالسؤال الأول ومناقشتها: وللإجابة عن السؤال الأول ونصه :ما مهارات القراءة المكثفة التي ينبغي تتميتها لدى طلاب الصف الأول الثانوي ؟

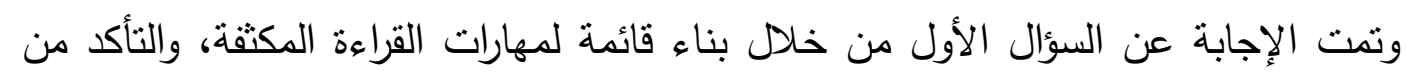
صدقها وثباتها والتحكيم عليها، وقد توصلت الباحثة إلى تحديد المهارات الآتية:

$$
\text { جدول (1) }
$$

قائمة مهارات القراءة المكثفة المناسبة لطلاب الصف الأول الثانوي

\begin{tabular}{|c|c|c|c|}
\hline المهارات الفرعية & r & مستويات القراءة المكثفة & م \\
\hline فهم الكلمة من خلال السياق. & 1 & \multirow{4}{*}{ الفهم المباشر } & \multirow{4}{*}{ الأول } \\
\hline إعطاء عنوان آخر للنص. & r & & \\
\hline تحديد الفكرة الرئيسية للفقرة . & $r$ & & \\
\hline تحديد الأفكار الجزئية. & $\varepsilon$ & & \\
\hline
\end{tabular}




\begin{tabular}{|c|c|c|c|}
\hline عدد يوليو & & سويف & جامعة \\
\hline المهارات الفرعية & 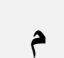 & مستويات القراءة المكثفة & b \\
\hline إدراك تتابع الأفكار الواردة في النص. & 0 & & \\
\hline استنتاج الأفكار الضمنية للنص. & 7 & \multirow{5}{*}{ الفهم الاستنتاجى } & \multirow{5}{*}{ الثاني } \\
\hline استنتاج العلاقات المتبادلة بين أفكار & v & & \\
\hline استتتاج هدف الكاتب من التص وإتجاهه. & $\Lambda$ & & \\
\hline استتتاج القيم الواردة بالنص. & 9 & & \\
\hline استتتاج التطبيقات الحياتية للنص. & 1. & & \\
\hline مناقشة الأدلة التي ساقها الكاتب. & 11 & \multirow{5}{*}{ الفهم الناقد } & \multirow{5}{*}{ الثالث } \\
\hline التمييز بين الآراء والحقائق في النص. & ir & & \\
\hline تبين الخطأ- إن وجد- في النص. & ir & & \\
\hline تحديد الأفكار التي لا ترتبط بالنص. & $1 \varepsilon$ & & \\
\hline تحديد مدى صحة الأفكار أو خطئها. & 10 & & \\
\hline إدراك الشعور المسيطر على جو النص. & 17 & \multirow{5}{*}{ الفهم التذوقي } & \multirow{5}{*}{ 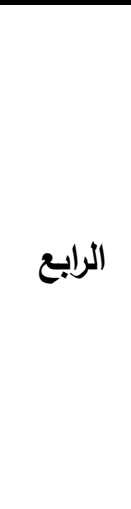 } \\
\hline تحديد سر الجمال في بعض التعبيرات في & iv & & \\
\hline تحديد أغراض بعض الأساليب في النص. & 11 & & \\
\hline إدراك الوحدة العضوية في النص. & 19 & & \\
\hline اختيار أقرب التراكيب اللغوية الدالة على معنى معين . & r. & & \\
\hline اقتراح بداية جديدة للنص & r & \multirow{5}{*}{ الفهم الابتكارى } & \multirow{5}{*}{ 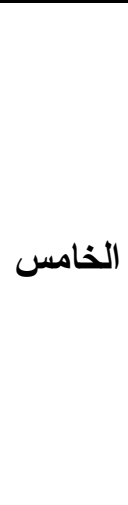 } \\
\hline اقتراح نهاية بديلة للنص. & rr & & \\
\hline اقتراح حلول جليدة لمشكلات وجدت في & $r r$ & & \\
\hline إضافة نتائج أخرى غير التي توصل إليها & $r \varepsilon$ & & \\
\hline إضافة أفكار داعمة للنص. & ro & & \\
\hline
\end{tabular}


ثانيًا :التتائج المتعلقة بالسؤال الثاني ومناقثتها: للإجابة عن السؤال الثاني ونصه :ما مدى تمكن طلاب الصف الأول الثانوي من مهارات القراءة المكثفة ؟ ولإجابة عن السؤال السابق قامت الباحثة بتطبيث اختبار القراءة المكثفة (الفهم المباشر الفهم الاستتناجي- الفهم الناقد - الفهم التذوقي - الفهم الإبتكاري ) وكانت نتيجة التطبيق القبلي التي توصلت إليها الباحثة كما يلي:

$$
\text { (r) جدول }
$$

مقارنة بين المجموعة الضنابطة والتجريبية لمهارات القراعة المكثقة في التطبيق القبلي

\begin{tabular}{|c|c|c|c|c|c|c|c|}
\hline الالالة & ت & درجات الحرية & الانحراف & المتوسط & العدد & المجموعة & المهارات \\
\hline \multirow{2}{*}{ غير دالة } & \multirow{2}{*}{.6181} & \multirow{2}{*}{77} & $.67 \wedge \varepsilon$ & r.r & $r \varepsilon$ & التجريبية & \multirow{2}{*}{ الفهم المباشر } \\
\hline & & & . ،VY & r.ro & r & الضابطة & \\
\hline \multirow{2}{*}{ غير دالة } & \multirow{2}{*}{ rror } & \multirow{2}{*}{79} & $.67 \mathrm{rV}$ & $r_{6} \cdot r$ & r & التجريبية & \multirow{2}{*}{ القهم الاستتتاجى } \\
\hline & & & $.6 V Y q$ & r.Ir & r & الضابطة & \\
\hline \multirow{2}{*}{ غير دالة } & \multirow{2}{*}{.6001} & \multirow{2}{*}{77} & $\cdot 67 \cdot r$ & $r_{6} \ldots$ & L & التجريبية & \multirow{2}{*}{ الفهم الناق } \\
\hline & & & $.67 \wedge 7$ & $16 \wedge \wedge$ & $r \varepsilon$ & الضابطة & \\
\hline \multirow{2}{*}{ غير دالة } & \multirow{2}{*}{$1, \varepsilon \cdot r$} & \multirow{2}{*}{77} & $.67 \leq 9$ & $r_{6} \cdot 7$ & $r \varepsilon$ & التجريبية & \multirow{2}{*}{ الفهم التذوقي } \\
\hline & & & $\Delta \bullet \Lambda_{6}$ & 1610 & $r \varepsilon$ & الضابطة & \\
\hline \multirow{2}{*}{ غير دالة } & \multirow{2}{*}{. ،૦人 } & \multirow{2}{*}{77} & .6181 & $.69 V$ & r & التجريبية & \multirow{2}{*}{ الفهم الابتكارى } \\
\hline & & & . . & $.69 \varepsilon$ & $r \varepsilon$ & الضابطة & \\
\hline
\end{tabular}

يتضح من الجدول السابق أن متوسط درجات المجموعة التجريبية ( Yr، I) بانحراف

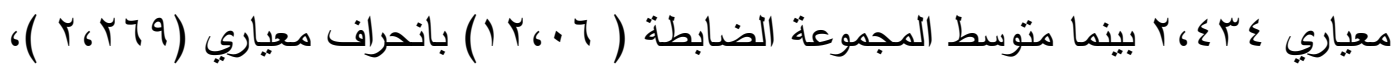
وعند حساب الدلالة تبين من الجدول أنه لا توجد فروق ذات دلالة إحصائية عند مستوى ا +. • وهذا بُفسر كما بلي: - تجانس المجموعتين التجريبية والضابطة . - عدم وجود فروق دالة إحصائيًا بين أقراد المجموعة التجربيية والمجموعة الضابطة في التظبيق القبلي 


\section{عدد يوليو}

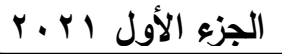

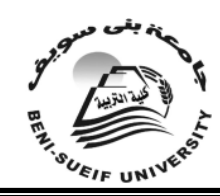

جامعة بني سويف

مجلة كلية التربية

لبطاقة الملاحظة في كل مهارة على حدة. ثالثًا :النتائج المتعلقة بالإجابة عن السؤال الثالث ونصهة: ما فاعلية استخدام خلية التعلم في تتمية مهارات القراءة المكثفة لدى طلاب المرحلة الثانوية؟ ولإجابة على هذا السؤال قامت الباحثة بتطبيق الاختبار التحصيلي لمهارة القراءة المكثفة تطبيقًا بعديًا، وذلك لحساب الفروق بين المجموعتين : الضابطة والتجريبية في مستوي مهارة القراءة المكثة البعدى لمجمل المهارات ، وذللك باستخدام (ت ) فكانت النتائج كما يلى: جدول (r)

حساب الفروق بين المجموعتين الضابطة والتجريبية في مستوي مهارة القراءة المكثقة البعدى لمجمل المهارات، وذلك باستخدام (ت)

\begin{tabular}{|c|c|c|c|c|c|c|}
\hline 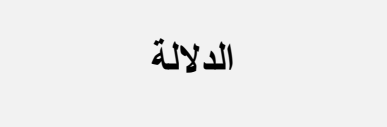 & $ت$ & الحرجية & الانعراف & المتوسط & 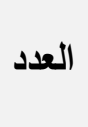 & المجموعة \\
\hline \multirow{2}{*}{ ץ ץ، أمستوي الالالة (كبير) } & \multirow[t]{2}{*}{$r_{6} \leq \varepsilon$} & \multirow{2}{*}{79} & r,IrI & rq.0. & $r \varepsilon$ & التجريبية \\
\hline & & & $r, T \leqslant \varepsilon$ & $1 \leq 6 V \leqslant$ & $r \varepsilon$ & الضابطة \\
\hline
\end{tabular}

يتضح من جدول السابق أن قيمة تدالة إحصائيًا، وحجم الأثر r,9 كبير، وهذا بعني وجود فروق ذات دلالة إحصائية بين منوسطي درجات الطلاب المجموعة التجريبية في مجمل الأداء الكلي لمهارات القراءة المكثفة (الفهم المباشر - الفهم الاسنتتاجى- الفهم الناقد- الفهر

التذوقي -الفهم الابتكارى) لصالح طلاب المجموعة التجريبية، ونلك في النظييق البعدي للاختبار. رابعا: النتائج المتعلقة بالإجابة عن السؤال الرابع ونصه: ما مهارات التفاوض المناسبة لطلاب الصف الأول الثانوي؟ وتمت الإجابة عن السؤال الرابع من خلا بناء قائمة لمهارات التفاوض، والتأكد من صدقها وثباتها والتحكيم عليها، وقد توصلت الباحثة إلى تحديد المهارات الآتية: 

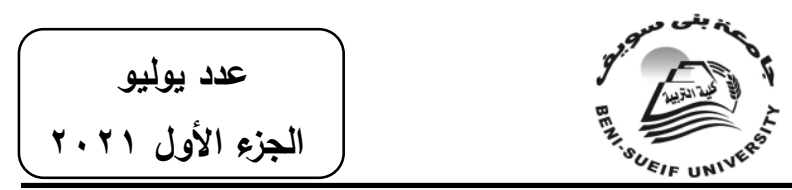

جامعة بني سويف

مجلة كلية التربية

\section{جدول (ع)}

يوضح قائمة لمهارات التفاوض المناسبة لطلاب الصف الأول الثانوي

\begin{tabular}{|c|c|c|c|}
\hline المهارات الفرعية & b & المهارات التفاوضية الأساسية & r \\
\hline الإلمام بجوانب موضوع التفاوض. & 1 & \multirow{6}{*}{ مهارة جمع البيانات وتحليل } & \multirow{6}{*}{ لأول } \\
\hline تحديد الأهداف من عملية التفاوض في ضوء البيئة التي & $y$ & & \\
\hline تعمل فيها والمشكلات التي تواجهها. & & & \\
\hline تنمية القدرات التفاوضية عن طريق التدريب النظري والعملي. & $r$ & & \\
\hline تحديد الموضوعات التي تؤثثر على عملية التفاوض. & $\varepsilon$ & & \\
\hline الإلمام بالظروف المحيطة. & $\bullet$ & & \\
\hline إجادة أساليب كسب احترام وثقة الطرف المقابل. & 7 & \multirow{5}{*}{ مهارة المعارف المتعددة ذات } & \multirow{5}{*}{ الثاني } \\
\hline تغيير اتجاهات الطرف المقابل & $v$ & & \\
\hline الوعي التام بمواقف وطلبات الطرف الآخر في عملية التفاوض. & $\wedge$ & & \\
\hline الإلمام بالأساليب السلوكية والإدارية للموقف. & 9 & & \\
\hline الاستعداد لتحمل المسؤولية و إصدار القرار. & 1. & & \\
\hline اتخاذ القرار والحكم الشخصي. & 11 & \multirow{5}{*}{ مهارة اتخاذ القرار التقاوضي } & \multirow{5}{*}{ 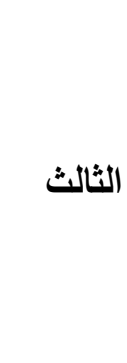 } \\
\hline الاتفاق على معظم بنود عملية التفاوض. & ir & & \\
\hline إصدار القرار النهائي وتحمل جميع ما يصدر عن إقراره. & ir & & \\
\hline التفاعل والتركيز لاستيعاب المشاكل المطروحة. & $1 \leqslant$ & & \\
\hline التقبد بوقت محدد للتفاوض. & 10 & & \\
\hline القدرة على تأكيد أو إثبات صحة ما يقال. & 17 & \multirow{5}{*}{ 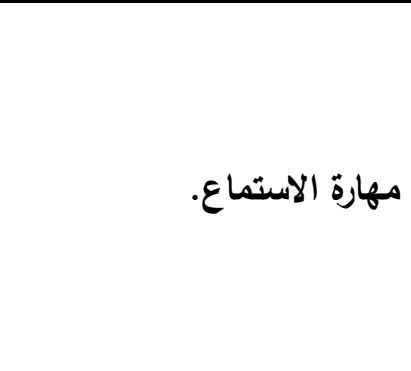 } & \multirow{5}{*}{ 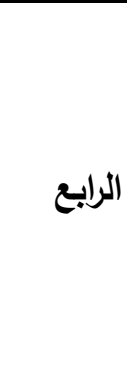 } \\
\hline فهم سؤال الجانب الآخر . & iv & & \\
\hline سرعة سير المفاوضات. & 11 & & \\
\hline عدم التسرع في المناقثة أو الحكم. & 19 & & \\
\hline القدرة على تقليم إجابات ملائمة. & r. & & \\
\hline القرة على طرح الأسئلة بلباقة. & r) & \multirow{2}{*}{ مهارة الاتصال } & \multirow{2}{*}{ 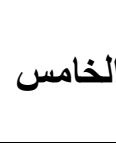 } \\
\hline القدرة على التعبير عن الأفكار شفهيًا. & rr & & \\
\hline
\end{tabular}




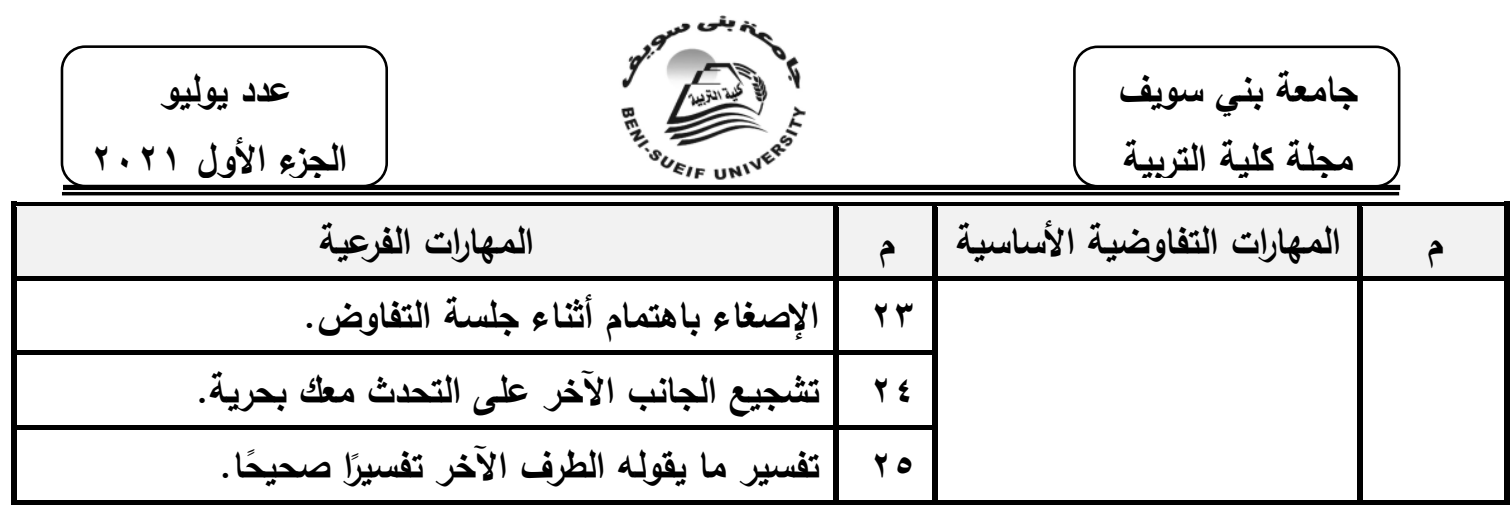

خامسا: النتائج المتعلقة بالسؤال الخامس ومناقشتها:

ولإجابة عن السؤال الخامس ونصه :ما درجة ممارسة مهارات التفاوض لدي طلاب

الصف الأول الثانوي ؟ ألهابه

وللإجابة على هذا السؤال تم استخدام التكرارات، والنسب المئوية، والمتوسطات الحسابية المرجحة للعبارات التي تقيس المهارات التفاوضية الفاعلة، وتخ عرض الثنائج على النحو التالي:

$$
\text { جدول (•) }
$$

المتوسطات الحسابية والأوزلن النسبية والمستوي والترتيب لمهارات التفاوض لاي طلاب الصف الأول الثانوي

\begin{tabular}{|c|c|c|c|c|}
\hline الترتيب & المستوي & الوزن النسبي & المتوسط الحسابي & 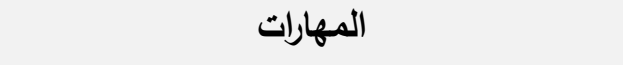 \\
\hline r & متوسط & 19601 & $\vee \bullet, 1$ & مهارة جمع البيانات وتحليل واستخدام المعلومات \\
\hline$r$ & متوسط & $0960 \ldots$ & Or 61 & مهارة المعارف المتعددة ذات الصلة بالتفاوض \\
\hline$\bullet$ & متوسط & $V r_{6} \leqslant V$. & $\left.\leq r_{6}\right)$ & 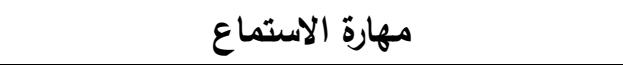 \\
\hline 1 & 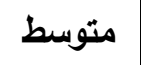 & $V V_{6} \circ 9$. & $v 961$ & مهارة الاتصال \\
\hline$\varepsilon$ & متوسط & 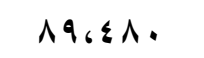 & $\varepsilon 1,1$ & مهارة اتخاذ القرار التفاوضي \\
\hline
\end{tabular}

يتضح من الجدول السابق أن المستوى الكلي لمهارات التفاوض لاى طلبة الصف الأول

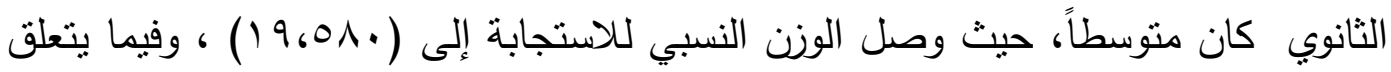

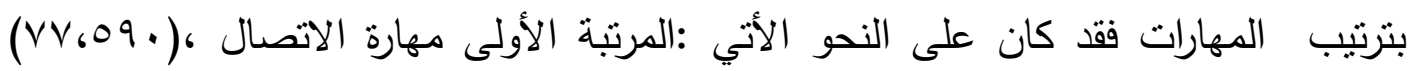

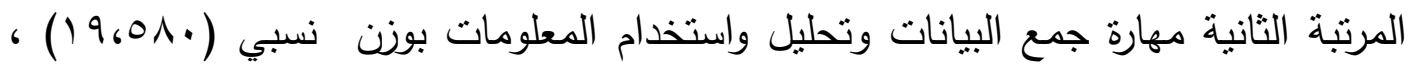
وفي المرنبة الثالثة مهارة المعارف المتعددة ذات الصلة بالتفاوض بوزن نسبي( . .0،ه)

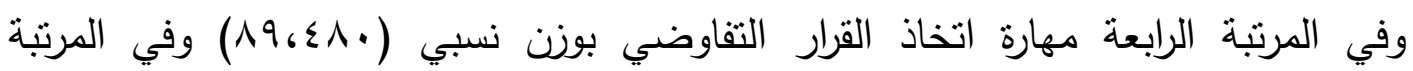

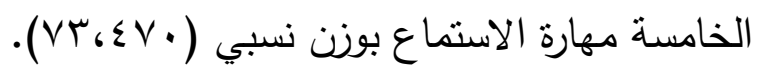




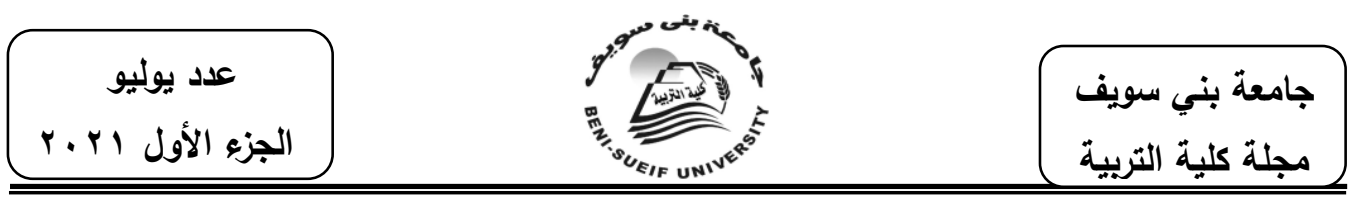

سابعا : تفسير النتائج :

إن استخدام خلية التعلم لها تأثيرها الفاعل فى تتمية مهارات القراءة المكثفة، وقد يرجع

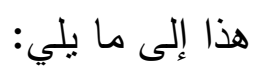

1 - استخدام خلية التعلم فى تدريس موضوعات القراءة، قد ساعد طلاب الصف على إتقان مهارات القراءة المكثقة. r - مرونة استخدام خلية التغلم التي تنتوعب مجموعة فعالة من الوسائل والأثوات فى سياق متع ومشوق. r- اعتماد بعض الأنشطة الإثرائية يعتبر محور العملية التعليمية، والقضاء على ملل الطلاب أثناء الموقف التعليمى ويساعد على زيادة الانتباه ويكسب الطلاب خبرات سارة جديدة من خلا المشاركة ويتحول المحتوى العلمي المجرد إلى صورة حية نابضة بالنشاط والحركة، تيسر على الطلاب الفهم، ويصبح ما تعلموه أبقى أثرًا.

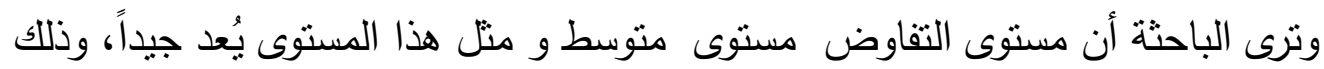
لأنه لا يتم الاهتمام مبكرا بمنل هذه المهارات في الأسرة وفي المدرسة، فعلى سبيل المثال

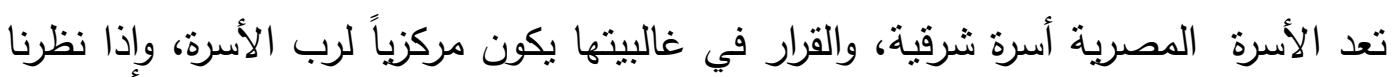
إلى المدارس فإنها تركز على المعلومة أكثر من المهارة، وما زال التعليم فيها تقليدياً، ومعيار القياس لتحصيل الطلبة يتم على كم المعلومات التي يحفظها الطلبة من المناهج الدراسية ، وليس ما يكتسبه الطالب من مهارات تقيده في حياته اليومية والعملية، أضف إلى ذلك إن المعلمين لا يشجعون مهارات التفاوض مع الطلبة وهناك حاجز بين المعلمين والطلبة، وما ينطبق على الواقع المصري ينطبق على الواقع العربي، لذلك أخذت بعض الدول منحى جديداً

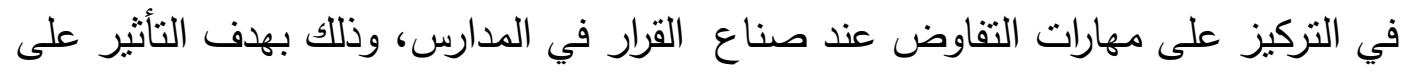
تتمية هذه المهارات لدى الطلبة. 


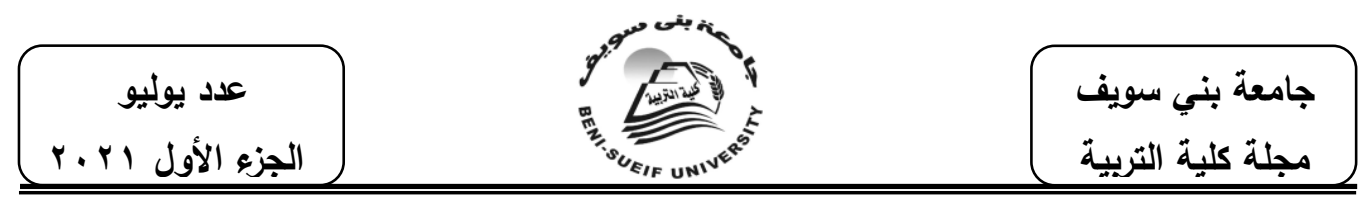

التوصيات والبحوث المقترحة

بناء على النتائج التي توصلت إليها الباحثة من خلال البحث الحالي، يمكن تقديم

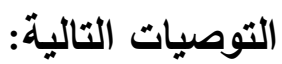

1 - ضرورة استخدام خلية التعلم في تتمية مهارات القراءة المكثفة ومهارات التفاوض لدى طلاب المرحلة الثانوية لما حفقته نتائج التجربة في هذا البحث. ץ- ضرورة الاهتمام بتتمية مهارات التفاوض في الدروس بين الطلبة والمدرسين، والطلبة مع بعضهم بعضاً، إضافة إلى الاهنمام في الأنشطة المساندة للمناهج الدراسية والتي تشجع التفاوض والحوار والمناقثنة لدى الطلبة. r - التدريب المستمر للطلاب علي استخدام خلية التعلم في تتمية مهارات القراءة المكثفة ومهارات التفاوض لدى طلاب المرحلة الثانوية ع - ضرورة تدريب معلمي اللغة العربية على صياغة الدروس باستخدام خلية التعلم في تتمية مهارات القراءة المكتفة ومهارات التفاوض لدى طلاب المرحلة الثانوية ه- تزويد المكتبات المدرسية بالكتب والمراجع والنشرات التي تعين المعلم على كيفية استخدام خلية التعلم في تتمية مهارات القراءة المكثفة ومهارات التفاوض لاى طلاب المرحلة الثانوية ج- زيادة الاهتمام بتتمية مهارات التفاوض لدى الإناث، حيث أظهرن مستوى أقل من الذكور والبدء في الاهتمام بتتمية مهارات التفاوض مبكرا لدى الطلبة، حيث أظهروا مستوى أقل في التي مهارات التفاوض مقارنة بالمستويات الدراسية الأخرى. V- عمل دورات تدريبية للمعلمين في أثناء الخدمة لتدريبهم على كيفية استخدام خلية التعلم في تتمية مهارات القراءة المكثفة ومهارات التفاوض لدى طلاب المرحلة الثانوية. 1- تخفيف الأعباء عن كاهل المعلم الذي يتبنى تدريس الموضوعات من خلال استخدام خلية التعلم بتخفيف عدد حصص اللغة العربية المخصصة له في الجدول المدرسي، وعدم مطالبته بحصص احتياطية أو أي أعباء أخرى. 9- تخصيص حوافز مادية للقائمين على استخدام خلية التعلم في تتمية مهارات القراءة المكثفة ومهارات التفاوض لدى طلاب المرحلة الثنانوبة 
• (- ضرورة تدريب المعلمين أثناء الإعداد الجامعي بكليات التربية على استخدام خلية التعلم في تدريس اللغة العربية بصفة عامة، والقراءة بصفة خاصة وذللك لأهمية خلية التعلم في اكتساب مهارات اللغة، والتحصيل.

1 1 - التركيز على الأنشطة الجماعية التي تنتح للمتطم أن يعلى ويفكر بطريقة جماعية تعاونية. r ا - ضرورة تجنب طرائق التدريس التي تعتمد على الإلقاء، على أن يستخدم المعلم ألوانًا

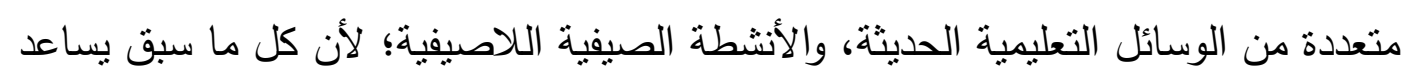
على تتمية مهارات القراءة.

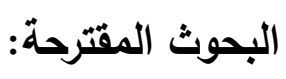

في ضوء ما توصلت إليه الباحثة من نتائج في هذا البحث ثقزح الباحثة القيام بالبحوث والدراسات التالية: ا - فاعلية خلية التعلم في تتمية مهارات القراءة في سائر المراحل والصفوف الأخرى. r - فاعلية خلية التعلم في تتمية مهارات الفهم القرائي في سائر المراحل والصفوف الأخرى. r - فاعلية خلية التعلم في تتمية مهارات التعبير الثفوي للمرحلة الابتدائية. ع - دراسة مقارنة لمعرفة نأثثر أكثر الأثثطة المدرسية الأخرى في نتمية مهارات القزاعة المكثةة. 


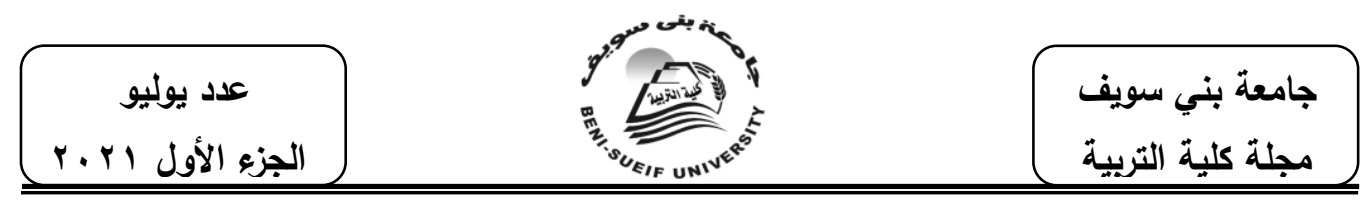

المراجع

أبو بكر بكر إسماعيل محمود(q . ץ): فاعلية طريقتي الاكتشاف الموجه والتعلم التعاوني في تتمية مهارات القراءة الناقدة لدي طلاب المرحلة الثانوية، رسالة ماجستير غير منشورة، كلية التربية،

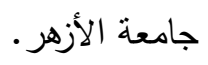

أكرم صالح الخوالدة (Y Y • Y):التقويم اللغوي في الكتابة والتفكير التأملي، عمان دار ومكتبة الخامد. جيفين كينيدى ( 11 (ب): قمة التفاوض لعقد الصفقات الرابحة والعلاقات الناجحة، نرجمة أمبرة نبيل، مركز الخبرات المهنية للإدارة، (إصدارات بميك)، القاهرة.

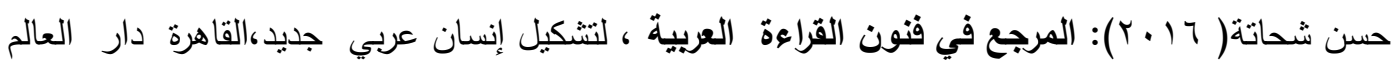
العربي.

حمدان علي نصر (r +. r): الموازنة بين تدريس القراءة الصفين الرابع والسابع من المرحلة الأساسية في

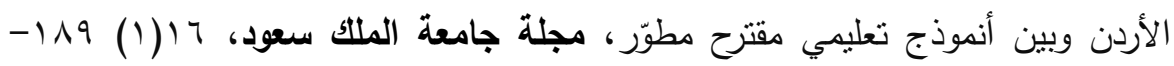

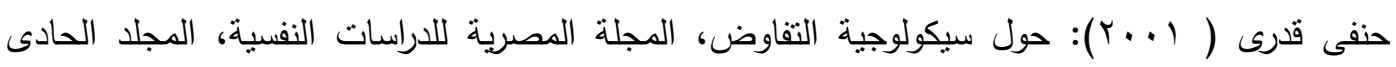
عشر ، العدد الثانى والثلاثون.

عبد الرحمن ثابت إدربس ( 10 • ( ) : التفاوض - مهارات واستراتيجيات، الدار الجامعية، الإسكندرية. عبد الناصر أنيس عبد الوهاب(^ . . ץ):أثز التدريب على استراتيجيات ما وراء المعرفة في مواقف تعاونية في تتمية مهارات الفهم القرائى لدى ذوى صعوبات التعلم بالمرحلة الابتدائية، مجلة القراءة

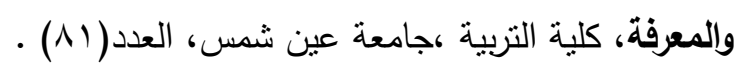

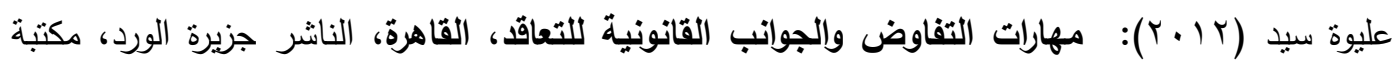
جزيرة الورد، القاهرة.

عمار طعمة الساعدي(r) (r): أثز استخدام التعلم النشط في تحصيل طلاب الصف الثالث المتوسط في الرياضيات، رسالة ماجستير غير منشورة، جامعة الموصل العراق.

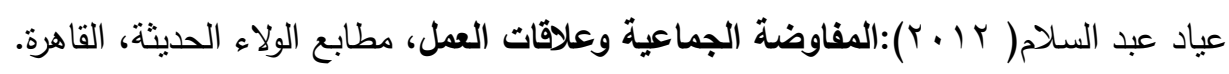
فاطمة بنت خلف الزايدي (9 . . ؟): أثز التعلم النشط في تتمية التفكير الابتكاري والتحصيل الدراسي بمادة العلوم ، لدى طالبات المرحلة المتوسطة ، رسالة ماجستير غير منشورة.

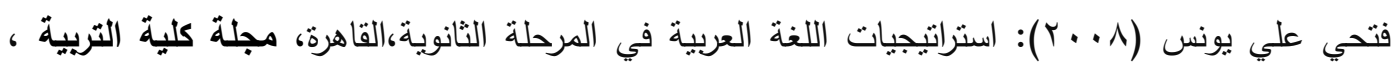
جامعة عين شمس. 


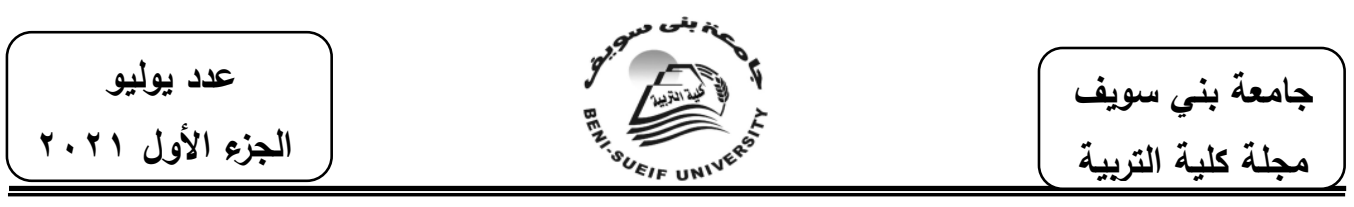

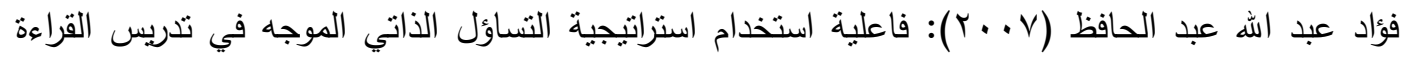
على تتمية الفهم القرائى والتفكير الناقد لدى طلاب المرحلة الثانوية،مجلة كلية التربية

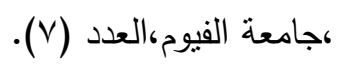

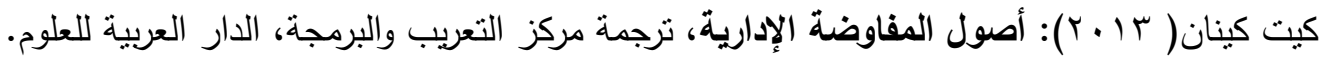

مجدي إبراهيم عزيز ( 9 . r): معجم مصطلحات ومفاهيم التعليم والتعلم، علم الكتب، القاهرة. محمد حبيب الله (9 . . r): أسس القراءة وفهم المقروء بين النظرية والتطبيق "المدخل فى تطوير مهارات

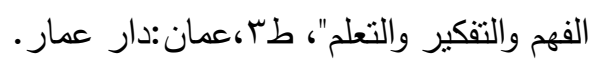

محمد زياد الأسطل ( • • ( ): أثز تطبيق استراتيجيتين التعلم النشط في تحصيل طلاب الصف التاسع ، في مادة التاريخ في تتمية تفكيرهم الناقد، رسالة ماجستير غير منشورة، جامعة الثرق

$$
\text { الأوسط. }
$$

محمد عبد الله محمد حسين الحاورى (V. . . . . أثز) برنامج في القراءة الابتكارية على تتمية بعض مهارات الكتابة لدى طلاب المرحلة الثانوية بالجمهورية اليمنية، رسالة دكتوراه غير منشورة ، كلية

$$
\text { التربية - جامعة عين شمس. }
$$

مروان أحمد السمان( ^1 • ب): برنامج قائم على مدخل التدريس المتميز لتتمية مهارات التعبير الثفوي والقراءة المكثفة، والكتابة التفسيرية، لدي تلاميذ المرحلة الإعدادية، مجلة العلوم التربوية ،

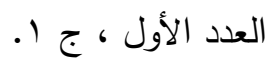

منصور سعد السحيمى (9 . . rم): العلاقة بين أنماط التركيب وفهم النص دراسة نظرية تطبيقية ، رسالة دكتوراه (غير منشورة)، كلية دار العلوم ،جامعة القاهرة.

هدى محمد صالح (^ . . ץ): الاتجاهات الحديثة في تعليم اللغة العربية في المرحلة الابتدائية ،القاهرة ،

$$
\text { مجلة كلية التربية ، جامعة عين شمس. }
$$

Lyons,N (2010) : Handbook of reflection and reflective inquiry : Mapping a way of knowing for professional reflective inquiry, U.S.A : sppringer

Kish, c.k . sheehan , j.k ,col,K.B. struyk , L.R and kinder , D.(1997) :

protfolios in the classroom : A vehicle for developing reflective thinking, the university of north carolina press.

Snow, C. (2012): Reading for Understanding", Science and Policy Institute, RAND Education, Office of Education Research and Improvement.

Duke, N. K., \& Pearson, P. D. (2001) Effective practices for developing reading comprehension. In .Farstrup A. E \& S. J. Samuels (Eds), What research has to say about reading instruction (pp. 206242). Newark, D.E.: 
عدد يوليو

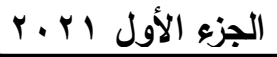

جامعة بني سويف مجلة كلية التربية

Menkel: Teaching absut (2010) Gender and Negotiation: sex, Truths and videatape. Negotiation J.,

Stuchlmacher, \& Champage ( 2010) The Impact of time Pressure and Information on Negotiation process and decision. Group Decision and Negotiation. 